OECDpublishing

\title{
THE DIGITAL INNOVATION POLICY LANDSCAPE IN 2019
}

OECD SCIENCE, TECHNOLOGY AND INNOVATION POLICY PAPERS May 2019 No. 71 
This paper was approved and declassified by written procedure by the Committee for Scientific and Technological Policy (CSTP) on 26 April 2019 and prepared for publication by the OECD Secretariat.

Note to Delegations:

This document is also available on O.N.E. under the reference code:

DSTI/STP/TIP(2017)5/REV3

This document, as well as any data and any map included herein, are without prejudice to the status of or sovereignty over any territory, to the delimitation of international frontiers and boundaries and to the name of any territory, city or area.

(C) OECD 2019

You can copy, download or print OECD content for your own use, and you can include excerpts from OECD publications, databases and multimedia products in your own documents, presentations, blogs, websites and teaching materials, provided that suitable acknowledgment of OECD as source and copyright owner is given. All requests for commercial use and translation rights should be submitted to rights@oecd.org. 


\title{
The digital innovation policy landscape in 2019
}

\author{
Sandra Planes-Satorra and Caroline Paunov
}

\begin{abstract}
How are OECD countries supporting digital innovation and ensuring that benefits spread across the economy? This paper explores the current landscape of strategies and initiatives implemented in OECD countries to support innovation in the digital age. It identifies common trends and differences in national digital, smart industry and artificial intelligence (AI) strategies. The paper also discusses policy instruments used across OECD to support digital innovation targeting four objectives: First, policies aimed at enhancing digital technology adoption and diffusion, including demonstration facilities for SMEs. Second, initiatives that promote collaborative innovation, including via the creation of digital innovation clusters and knowledge intermediaries. Third, support for research and innovation in key digital technologies, particularly AI (e.g. by establishing testbeds and regulatory sandboxes). Fourth, policies to encourage digital entrepreneurship (e.g. through early-stage business acceleration support).
\end{abstract}

Keywords: innovation and research policy; digital innovation; innovation strategies; digital technologies and artificial intelligence (AI).

JEL: O30, O31, O33, O38, O25, I28

Acknowledgements: The authors would like to thank Dominique Guellec as well as the experts and delegates to the OECD Working Party on Innovation and Technology Policy (TIP) and the OECD Committee for Scientific and Technology Policy (CSTP) for their comments to the previous versions of the paper. 


\section{Table of contents}

Introduction 5

1. Innovation policy in the digital age: rationales and perspectives from the system transformation approach 7

1.1. Rationales for innovation policy in the digital age ................................................................ 7

1.2. Adopting a systems innovation policy approach to address the challenges of the digital age.... 11

2. Innovation policy strategies for the digital age ..................................................................................... 14

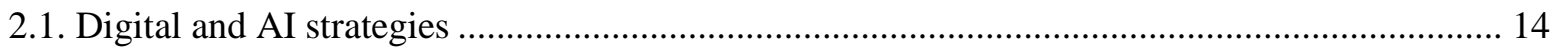

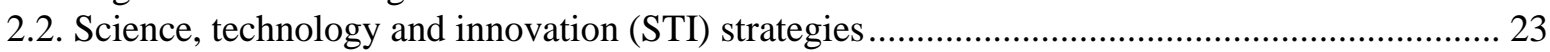

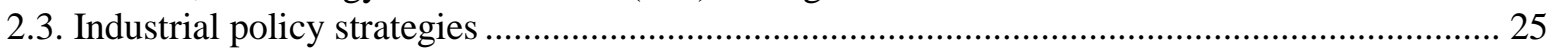

3. Innovation policy initiatives for the digital age................................................................................. 28

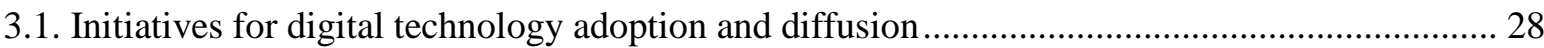

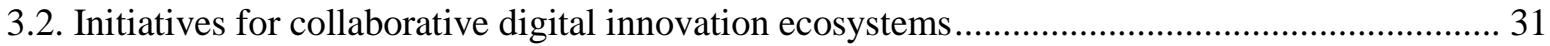

3.3. Initiatives to support research and innovation in digital technologies ...................................... 36

3.4. Initiatives to support innovative entrepreneurship in the digital age ....................................... 40

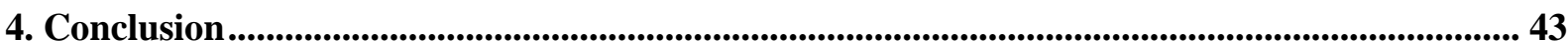

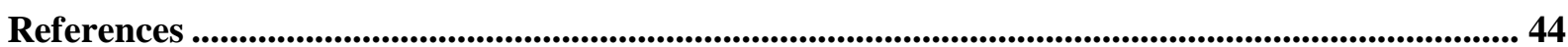

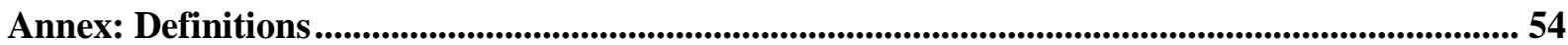




\section{Introduction}

Digital technologies are transforming innovation processes and outcomes. They are enabling the creation of new digital or digitally enabled products and business models, such as online marketplaces and on-demand mobility services, and the enhancement of traditional ones, as exemplified by connected cars. Digital technologies also transform innovation processes, as big data analytics, virtual simulation and 3D printing offer new opportunities for developing, prototyping and testing new products. However, the potential of digital innovation is often not realised. Not all actors are prepared to do such efforts, which risks widening the productivity gap between the tech leaders and the rest (OECD, 2019). In this context, what are countries doing to support digital innovation and ensure that benefits spread across the economy? What are specific innovation policy strategies and initiatives in place?

This paper discusses the mandate for innovation policy requirement in the digital age and provides an overview of the innovation policy strategies and initiatives recently implemented in different countries to facilitate a successful transition towards a digital economy. The overview explores the main features of strategies and discusses the initiatives adopted to enhance digital technology adoption and diffusion; promote collaborative innovation; support research and innovation in key technologies; and encourage digital entrepreneurship.

Regarding the policy mandate, the paper emphasises that innovation policies are very relevant. Policies need to address a number of capability and market failures that affect innovation ecosystems in the context of digital transformation. Policy can notably help support digital technology diffusion and assist firms digitally transform as well as ensure that digital innovation contributes to tackle emerging societal and environmental challenges. Adopting a 'system innovation' policy approach - which consists in designing innovation policy considering the entire policy mix and the interlinkages across policy domains in order to tackle complex societal challenges - is important to shape innovation policies in the digital age. Steering such a system transformation requires to jointly build a shared vision for the future to exploit technological opportunities in light of socio-economic objectives.

New policy strategies (i.e. strategies or plans setting the vision, priorities and general guidelines for policy action) have been developed in many countries to respond to the new needs and challenges that characterise the digital age. Most countries have dedicated national digital strategies, and many are starting to develop or have recently launched their artificial intelligence (AI) strategies, including Canada, France, South Korea and the UK. Digital-innovation related objectives are also often central in general science, technology and innovation strategies (e.g. in the New High Tech Strategy in Germany and the $5^{\text {th }}$ Science and Technology Basic Plan in Japan). New emphasis is placed on industrial policies, adopted in many countries to ensure that national economies develop competitive advantages in emerging sectors and embrace opportunities offered by Industry 4.0. Examples include the National Plan Industry 4.0 in Italy and the Smart Industry Strategy in Sweden. 
Countries are also experimenting with new policy approaches or instruments, while traditional ones (e.g. grants, capacity building support) are being adjusted to respond to emerging needs. To enhance digital technology adoption and diffusion, some countries are establishing new facilities for demonstration and testing of new technologies (e.g. SME 4.0 Competence Centres in Germany, Norwegian Catapult Centers), providing financial support for digital technology investments and other support services (e.g. SMEs Programme for Smart Manufacturing in South Korea and Service design vouchers for manufacturing SMEs in the Netherlands) and facilitating access to state-of-the-art facilities and expertise (e.g. High Performance Computing Centres in many European countries).

New collaborative research and innovation centres have been created to foster multidisciplinary research and co-creation (e.g. Data61 in Australia, Smart Industry Fieldlabs in the Netherlands). Collaborative innovation is also fostered with the creation of intermediaries that facilitate the matching across different actors in the innovation ecosystem (e.g. Digital Catapult in the UK) and clusters (e.g. Digital Hub Initiative in Germany). Some countries are experimenting open innovation tools, such as crowdsourcing, open challenges and living labs, to find innovative solutions to pressing challenges (e.g. Citizenscience.gov in the US, the City of Things in Antwerp, Belgium).

To strengthen research and innovation in key digital technologies, such as AI and big data analytics, financial support is being provided to both businesses (e.g. Smart and Digital Services Initiative) and public research organisations (e.g. Robust Intelligence Programme in the USA). Test beds and regulatory sandboxes are also being deployed in some countries to allow for experimentation in near to real-world conditions.

Policy instruments to support digital entrepreneurship range from early-stage business acceleration support (e.g. National Digital Research Centre in Ireland), to the creation of a brand to increase the reputation of national digital start-ups abroad (e.g. La French Tech Initiative) and the development of networks (e.g. boot camps organised by Start-up Sweden).

This paper does not provide an exhaustive account of policy strategies and initiatives across countries, but offers an overview of policy trends. It builds on information from country responses to the 2018 European Commission/OECD Science, Technology and Innovation Policy Survey and the 2017 OECD Digital Economy Outlook questionnaire; policy case studies contributed by countries to the OECD TIP project on Digital and Open Innovation; and desk research. Examples have been chosen to illustrate diverse policy approaches from OECD and non-OECD countries.

The policy collection presented in this paper informed the final report of the Digital and Open Innovation project (OECD, 2019), conducted by the OECD Working Party on Innovation and Technology Policy (TIP) and aimed at helping innovation policy makers identify priority areas for innovation policy action and reform, so as to promote innovation and inclusive growth in the digital age. The paper also contributes to the OECD Going Digital project.

The paper is structured as follows. Section 1 discusses the rationales for innovation policies in the digital age and how a 'system innovation' policy approach can support the design of such policies. Section 2 identifies common trends and distinctive features of policy strategies aimed at fostering innovation in the digital age. Section 3 explores the range of policy initiatives and instruments recently implemented in different countries to address digital innovation-related objectives. Section 4 concludes. Definitions of key terms used in the paper are provided in the Annex. 


\section{Innovation policy in the digital age: rationales and perspectives from the system transformation approach}

This section explores the rationales for innovation policy in the digital age, and how a system innovation policy approach can support the design of such policies.

\subsection{Rationales for innovation policy in the digital age}

Innovation is a key driver of growth and wellbeing: it contributes to enhancing business productivity and competitiveness, boosting job creation and addressing social and environmental challenges. Policies to promote innovation have been implemented in response to a number of "failures" that affect innovation ecosystems and that may result in less innovation than would be desirable from a societal perspective (OECD, 2015c). Digital transformation may exacerbate some of those failures, in particular:

- Capability and resource failures. Insufficient know-how to deploy new technologies or implement organisational changes to adapt to them hinders innovation. In the context of digital transformation, disparities in terms of capacities and resources across firms and sectors to adopt new digital technologies may not only reduce the potential of those innovations to foster productivity and growth, but also contribute to increasing gaps in productivity performance across firms and sectors. This may result in a "dual economy", where the innovative, technologically advanced and highly productive sectors coexist with the traditional, low productive sectors that benefit little from new technologies (see Planes-Satorra and Paunov, 2017).

- Market failures and imperfections. These arise when private returns to innovation are lower than social returns due to knowledge spillovers. These may not allow the inventor to appropriate all benefits from the innovation, lowering incentives to innovate (although there are mechanisms to reward investments in the creation of knowledge, such as intellectual property rights). Digital transformation may increase knowledge spillovers (particularly due to the fluidity of data, i.e. the fact that digitised knowledge or information can circulate and be reproduced, shared or manipulated instantaneously by any number of actors regardless of their location), which could lead to lower levels of investment in innovation. Other market failures include biases in the markets towards existing technologies (technology lock-ins ${ }^{1}$ ), and barriers to entry that arise from increasing economies of scale and network effects (i.e. when the value of a product or service increases with the increase of users, as is the case of digital platforms). Barriers to access data for innovation purposes (e.g. due to legal and contractual barriers) also hinder innovation in the digital age (see Guellec and Paunov, 2019; OECD, 2019). created. 
- Barriers faced by innovative entrepreneurs. Innovative entrepreneurs may face barriers to access finance for innovation and suitable support infrastructure (e.g. support from research institutions), among others. Lack of sufficient assets to overcome those barriers (e.g. limited resources to build internal research capacities) may hinder the success of innovative entrepreneurs (IPP, 2017a). The high dynamism and risks associated with the digital economy (where new products may be very successful or fail completely) may add further challenges regarding access to finance for SMEs, as demonstrating the value of new products or business models to providers of finance may be harder.

- Absence of enabling conditions for productive investment in innovation. Barriers hampering investments in innovation include inadequate ICT and research infrastructure and regulatory uncertainty regarding new digital or digitally-enabled products, processes or business models. For example, the lack of legislation concerning some innovative business models facilitated by digital technologies (e.g. in the sharing economy) may produce uncertainties and consequently limit investments in such innovations.

- Co-operation failures within the innovation system. Some barriers might prevent the creation of linkages and networks among researchers and innovators in the innovation ecosystem (incl. firms, universities and public research institutes), such as the misalignment in interests and motivations for research and innovation. For example, public researchers may have higher incentives to conduct fundamental research that can be freely diffused, regardless of its commercial potential, and plan activities over long time periods; while private organisations have incentives to focus on applied research and plan activities around short term financial criteria and product development cycles (IPP, 2017b).

Innovation policies supporting businesses, public research and science-industry linkages in the context of digital transformation can play a key role in addressing these barriers, particularly by:

- Promoting digital technology diffusion and adoption by businesses: New digital technologies are developing quickly and may not diffuse evenly and pose challenges in a period of rapid and frequent change. Small firms, for example, tend to use emerging technologies less frequently than large firms (OECD, 2017a). There are many examples of this. Data for the UK show that in 2014, $21 \%$ of smaller firms (10-49 employees) in the country were using cloud computing services, compared to $54 \%$ of large firms (250 or more workers) (OECD, 2015a). This is partly explained by the lack of information, skills, expertise, training, resources and confidence to adopt new technologies. Technological lock-ins can also be behind low adoption of more advanced technologies (OECD, 2017a). Innovation policies can play a key role in addressing those market failures by promoting technology diffusion and helping companies to digitally transform.

- Facilitating innovative entrepreneurship, start-ups and experimentation in the context of the digital transformation: Innovative entrepreneurship that builds on possibilities of digital technologies is critical not only for competitiveness in this very dynamic economic sector but also to facilitate the adoption of digital technologies (as these firms acquire capabilities that allow adopting digital technologies to the specific national context). Digital start-ups, however, frequently face well-known barriers to establish themselves and grow, for example, with 
regards of access to finance and research infrastructure. Cumbersome regulatory frameworks affecting the flexibility of businesses to experiment with digital innovations may also hinder gains from the digital transformation. Innovation policies are critical to address those barriers, for instance, by creating regulatory sandboxes, living labs and testbeds (OECD, 2015b).

- Building strong R\&D capacities in cutting-edge technologies: Countries with strong capacities to develop and adopt key emerging digital technologies (e.g. Internet of Things, big data analytics, cloud computing, simulations, additive manufacturing) will be better positioned to take up the vast opportunities they will offer for industry, and to reap possible benefits from being first to offer technologies in globalised competitive markets. Innovation policies can play a key role in promoting $R \& D$ investments and strengthening the capacities in core sectors and technology areas, addressing a number of barriers that may otherwise prevent firms and research institutions to engage in these core investments.

- Fostering collaborations for innovation: In the new context, firms rarely have all capabilities to fully develop new technologies on their own (e.g. the automotive industry increasingly relies on innovations in artificial intelligence from outside the industry). The increasing need for multi-disciplinary cooperation and the blurring lines between sectors make collaboration across companies and between companies and public research actors (both within and across countries) increasingly important. In addition, in a context of rapid technological changes, it is critical that research findings are rapidly translated into innovative goods and services. Innovation policies can set the appropriate frameworks to enhance vibrant innovation ecosystems, encourage science-industry linkages and business-tobusiness collaborations (also across countries), and facilitate the rapid transformation of innovations from the laboratory to production.

- Addressing emerging societal challenges: Innovation faces growing demands to address global challenges, including those set out by the United Nation's Sustainable Development Goals regarding poverty, the environment, health, education, food and water security, and affordable and clean energy (OECD, 2016; UN, 2015). Digital innovations can contribute to address some of those challenges (Box 1). For example, some digital health and online learning applications have the potential to increase the welfare of disadvantaged groups, while big data analysis and AI applications can improve disaster management systems and provide solutions to environmental challenges (OECD, 2017b; OECD, 2015d; Chui et al., 2018). Innovation policies can foster inclusive and sustainable growth by providing the appropriate incentives to encourage research and innovation actors to develop digitally-enabled responses to emerging challenges. This requires not only promoting investments but also encouraging collaborations, as responses to complex challenges may only come from multidisciplinary approaches. 


\section{Box 1. The potential of digital technologies for inclusive growth}

Throughout history, technological change and innovation have fuelled massive socio-economic transformations that have greatly raised living standards across societies. Today, new digital technologies offer opportunities for improving the well-being of disadvantaged and excluded groups. As explained in more detail in OECD (2017b), digital technologies are already improving education, health and government services in ways that have favoured social inclusion.

Unlike classroom-based education, online learning is accessible from any location with an Internet connection and at lower costs, often for free. Learning platforms reach peripheral locations and allow flexibility to accommodate individual needs in terms of study schedules and approaches to learning. Massive Open Online Courses (MOOCs) provide key opportunities for online learning. They are structured online lectures aiming to offer mass participation with open (often free) access via the web. Evidence suggests that online courses expand access to higher education for students who would not otherwise enrol (Goodman, Melkers and Pallais, 2016).

Digital health services, delivered or enhanced through the Internet and related digital technologies, enable better access and more personalised health services. Information technology benefits those suffering from chronic diseases and disabilities, groups in society that are often threatened by exclusion. A critical source of welfare gains comes from progressively making treatment more personalised. For instance, diabetic patients can more easily assess their need for insulin through personal devices. Practitioners can more quickly detect urgent maladies as a result of the analytical capabilities embedded in medical equipment. Several new digital technologies, including the Internet of Things and artificial intelligence, promise additional gains as they are further deployed.

Digital government refers to the use of digital technologies by public administration, including for delivery of public services. Digitalisation has already contributed to social inclusiveness by increasing public service quality, efficiency and reach. The opportunities to file taxes and apply to services on line has made application procedures more convenient, benefitting in particular individuals located in remote areas as well as those from lower-income and excluded groups, as they rely more on allocations and subsidies. Furthermore, several digital services favour civic engagement. These include sending filled-in forms to government agencies or public authorities, filing petitions on line, taking part in online consultations or voting to define civic or political issues (Eurostat, 2015). Civic engagement allows minorities, individuals at the lower end of the income distribution and the less educated to engage more (McElwee, 2014).

The potential of digital technologies, including AI, for addressing societal and environmental challenges is broad and expanding (see Chui et al., 2018). Measuring the impacts of such applications however remains challenging, given the largely non-monetary nature of welfare gains associated to digital innovations.

Source: OECD (2017b). 


\subsection{Adopting a systems innovation policy approach to address the challenges of the digital age}

The system innovation approach consists in designing innovation policy considering the entire policy mix and the interlinkages across policy domains in order to tackle complex societal challenges that are systemic in nature. In recent years, the OECD's Working Party on Innovation and Technology Policy (TIP) has been studying how the 'system innovation' concept could help innovation policy steer the transition towards more sustainable and green economies (OECD, 2015e).

Digital transformation is a process that brings about fundamental changes in economic and social systems, permeating increasingly all sectors of the economy and social spheres. The 'system innovation' policy approach can thus provide a number of insights for thinking about innovation policies in the digital age, aimed at supporting innovation and inclusive and sustainable development; these are presented below.

\section{(1) Developing balanced and well-aligned policy mixes}

A range of aligned policy instruments are needed in order to steer systems change. Discrete policy interventions are unlikely to be sufficient to steer systems change; and even when single instruments succeed, they may result in unintended consequences and shift problems elsewhere in the system. It is thus critical to develop a balanced and well-aligned policy mix, if possible that includes both supply- and demand-side instruments to foster innovation and inclusive development in the digital age. Alignment is needed not only among innovation policies but also with other policy domains (e.g. research, education, competition, tax). Intergovernmental committees and platforms have been used in many countries to ensure coordination among multiple policy instruments.

\section{(2) Engaging key stakeholders and citizens in policy making processes}

Establishing mechanisms for multi-stakeholder engagement can be key to overcome resistance to change, often an important barrier to system transformation. Such mechanisms help build trust, create a shared and comprehensive vision of the transformation and facilitate the coordination of actions in the right direction. Examples include engaging key stakeholders (from industry and academia but also citizens, in order to better understand their needs) in roadmapping, creating multi-stakeholder platforms or forums for discussion (e.g. Industry Platform 4.0 in Austria and Germany - see box 3 in section 2.3), and involving citizens in the process of validation of new technology solutions. For instance, the development of the Automotive Technology Roadmap to foster the transition towards low carbon vehicles in the UK involved the senior level from business and research institutes to ensure that the outcome represented an industry-wide view (Automotive Council UK, 2018). The strategic innovation programme Bioinnovation in Sweden - aimed at fostering the transition towards a bio-based economy by 2050 - promotes the active engagement of users for ensuring the market-relevance of innovation projects (BioInnovation, 2018).

\section{(3) Fostering cross-sectoral collaboration for innovation}

Addressing complex societal challenges requires the contributions of and collaboration among different actors, including across industry sectors and academic disciplines. For instance, one of the pillars of the strategic innovation programme Bioinnovation in Sweden is to promote the cross-fertilisation of competences and experiences by stimulating 
interaction and collaboration across sectoral boundaries (BioInnovation, 2018). The Nano4Health project in Belgium shows how inter-cluster collaboration between DSP Valley and FlandersBio (the main Flemish clusters on micro-electronics and life sciences, respectively) is key to develop innovative personalised health care solutions at the crossroads of nano- and biotechnology (European Cluster Collaboration Platform, 2016).

Similarly, innovation in the context of digital transformation increasingly requires new mixes of competences and technologies. Companies often need to rely on external resources of knowledge for innovation and engage in partnerships with established and new firms, both within and across sectors. Policy instruments such as cluster policies and collaborative research centres can be thus be important (see section 3.2).

\section{(4) Strengthening policy intelligence}

The complexity of system transformations (and digital transformation) requires mechanisms to enhance policy intelligence and strengthen the policy makers' understanding of the ongoing processes, as well as the barriers and facilitators in specific sectors and technology domains. Several tools can support this. Strategic foresight can help detect impulses for change when their signals are only weak, helping to identify opportunities, threats or vulnerabilities early on, while roadmapping allows gathering the collective knowledge and allows developing a shared vision among stakeholders.

Countries are also experimenting with new approaches. In the Netherlands, a broad consultation and a decision-tree framework was used to assess whether or not the government should regulate new digital platforms, as well as bring to light outdated regulation that stifles innovative developments. The framework also allowed identifying many areas in which there was no need for new regulation, but for clarification of existing laws (Kes, 2016). In Belgium, a back-casting approach (i.e. stating the desired future up front rather than deriving it from scenarios or forecasts) was used to identify where the transformation of the system towards a bio-based economy was held back. The approach identified barriers to the uptake of bio-based products by end-user sectors (Diels, Dhooge and Creten, 2016).

As system transformations (and digital transformation) are open-ended and uncertain processes, it is important to have room for policy learning and adjustments. Systematic monitoring and evaluation of public policies is needed to ensure regular feed-back into policy design. Sharing of experiences internationally can also facilitate policy learning, extend policy horizons and improve impact over time.

\section{(5) Adapting policy to the different stages of technology and market maturity}

Identifying the phase of the transformation helps designing more tailored policy tools. At a very early phase of the transition, priority setting and foresight exercises such as roadmapping are important policy instruments to develop a shared vision among actors and to co-ordinate actions and interests in the right direction.

At the pre-development phase, providing support for networking among actors is important to enhance the collaborative activities and share knowledge. Co-funding of R\&D projects by government at early stages in technology development can help de-risk projects and create an environment in which companies are more confident to invest in R\&D. Pilot and demonstration support can also be used to bridge the gap between R\&D and widespread commercialisation of a technology by showing the operation and workability of proofs of concepts. 
At the take-off phase, reviewing, clarifying or updating existing regulations and legislation might be required to remove institutional barriers to market entry. Demand side policies such as public procurement can also be critical to accelerate the uptake of new technologies.

In the context of digital transformation, similar frameworks could be used to identify the range of policies most suitable to support research and technology development at different stages of maturity. Moreover, different actors have different levels of digital capacities and thus face different challenges that can be tackled by policy: high-tech start-ups are more likely to face regulatory or other barriers to develop their digital activities, while laggard SMEs may require awareness rising and skills upgrading support. 


\section{Innovation policy strategies for the digital age}

Digital transformation has wide-ranging effects on the economy and society, thus having implications in practically all policy domains -from education and labour to innovation and health policies. New policy strategies (i.e. strategies or plans setting the vision, priorities and general guidelines for policy action) have been recently developed in many countries to respond to the new needs and challenges that characterise the new digital context. This section explores how digital transformation objectives have been integrated in policy strategies having effects on innovation: 1) National digital strategies and AI strategies; 2) Science, technology and innovation strategies; and 3) Industrial policy strategies.

\subsection{Digital and AI strategies}

\section{National digital strategies}

Most OECD countries have a national digital strategy, agenda or programme, according to the OECD Digital Economy Outlook policy questionnaire conducted in 2016. Such strategies aim to maximise the social and economic potential of digital technologies, as a means of spurring innovation, growth and wellbeing (Table 1). Some countries, such as the Russian Federation and the USA, do not have an overarching national digital strategy, but have implemented strategies and policies focused on specific issues or sectors (OECD, 2016b).

National digital strategies have traditionally focused on supply-side objectives, such as promoting the development of digital infrastructures, improving access to broadband in underserved areas, and supporting the digital sector. Over the past years, most of them have progressively integrated specific demand-side objectives, such as promoting the adoption of digital technologies by businesses, particularly among SMEs and firms in traditional sectors, and expanding digital skills and competences across society, to foster social inclusion and facilitate the adaptation of workers to new labour market demands (OECD 2016b).

According to the OECD Digital Economy Outlook questionnaire conducted in 2016, practically all national digital strategies have the objectives of further developing telecommunication infrastructure, strengthening e-government services, increasing digital security, promoting ICT-related skills, advancing e-inclusion (e.g. of the elderly and disadvantaged groups), and increasing the use of digital technologies. Other objectives appearing only in some strategies are enhancing access to data, strengthening privacy, promoting e-commerce, and preserving Internet openness.

A new area of focus in recent strategies is data access - critical in a context where data has become a key input for innovation (see OECD, 2019). For instance, the digital strategies of Australia and the UK emphasize the importance of promoting actions for capturing the value of data, enhancing data access, managing privacy and security, increasing citizen's trust in the use of data, and building data science capabilities (Australian Government, 2018; Department for Culture, Media and Sport, 2017).

Developing sound regulatory approaches for digital environments is another new area of focus. For instance, Digital Belgium envisages the implementation of innovation-friendly 
legislation so that innovative business models facilitated by digital technologies (e.g. in the sharing economy) can operate in a legally stable framework (Digital Belgium, 2017). The Australian strategy highlights the importance of developing fit-for-purpose and flexible regulations, tailored to innovative digital practices, including through technology-neutral and outcomes-focused approaches. Consistent regulations and standards, and participation in shaping global standards, are also among the main objectives (Australian Government, 2018).

Table 1. Examples of national digital strategies

\begin{tabular}{|c|c|}
\hline & Main objectives \\
\hline$\frac{\text { Australia's Tech Future }}{\text { (Australia) }}$ & $\begin{array}{ll}\text { - } & \text { Develop people's digital skills so as to ensure inclusive society; } \\
\text { - } & \text { Improve the delivery of governmental services online (e-government); } \\
\text { - } & \text { Build infrastructure and provide secure access to high-quality data; } \\
\text { - } & \text { Strengthen cyber security and review the regulatory systems. }\end{array}$ \\
\hline$\frac{\text { Digital Belgium }}{\text { (Belgium) }}$ & $\begin{array}{l}\text { - } \quad \text { Promote the digital economy; } \\
\text { - } \quad \text { Invest in digital infrastructure; } \\
\text { - } \quad \text { Strengthen digital confidence and security; } \\
\text { - } \quad \text { Promote digital skills and jobs; } \\
\text { - } \quad \text { Develop digital government. }\end{array}$ \\
\hline $\begin{array}{l}\text { Doing more with Digital } \\
\text { (Ireland) }\end{array}$ & $\begin{array}{ll}\text { - } & \text { Support trading online and digital entrepreneurship; } \\
\text { - } & \text { Use ICTs to its full potential across the education system; } \\
\text { - } & \text { Increase the number of Internet users; } \\
\text { - } & \text { Improve the delivery of governmental services online (e-government). }\end{array}$ \\
\hline$\frac{\text { ICT for Everyone - A Digital }}{\text { Agenda for Sweden }}$ & $\begin{array}{l}\text { - } \quad \text { Make the Internet and other digital services easy and safe to use; } \\
\text { - } \quad \text { Promote the development of digital services that create benefit; } \\
\text { - } \quad \text { Develop digital infrastructure; } \\
\text { - } \quad \text { Strengthen the role of ICT for societal development. }\end{array}$ \\
\hline$\frac{\text { UK Digital Strategy } 2017}{\text { (UK) }}$ & $\begin{array}{ll}\text { - } & \text { Build world-class digital infrastructure; } \\
\text { - } & \text { Give everyone access to the digital skills they need to foster social inclusion } \\
\text { - } & \text { Make the UK an attractive place to start and grow digital businesses; } \\
\text { - } & \text { Help businesses adopt digital technologies; } \\
\text { - } & \text { Strengthen cybersecurity; } \\
\text { - } & \text { Further develop e-government; } \\
\text { - } & \text { Unlock opportunities provided by data and improve public confidence on its use. }\end{array}$ \\
\hline
\end{tabular}

Source: Australian Government, 2018; Digital Belgium, 2017; Department of Communications, Energy and Natural Resources, 2013; Government Offices of Sweden, 2011; Department for Culture, Media and Sport, 2017. 


\section{Artificial Intelligence (AI) strategies}

Countries have also recently adopted or are working to develop strategies to maximize the economic and societal benefits of Artificial Intelligence (AI). Canada was the first country to adopt such a strategy in March 2017 -a five-year plan to invest mainly in AI research and talent. It has been followed by many others, including Japan (March 2017), the People's Republic of China (October 2017), France (March 2018), the UK (April 2018), South Korea (May 2018), Germany (November 2018) and the USA (February 2019). At the EU level, the recent Communication on Artificial Intelligence for Europe (released in March 2018) and the associated Coordinated Plan on AI (December 2018), which aim to foster the development and use of AI in Europe, encourage EU member states to develop such strategies (European Commission, 2018a).

AI strategies adopted to date are however quite diverse. AI strategies can be divided in two groups: 1) strategies that set a specific action plan and provide direct funding for AI programmes (or have been directly followed by budgetary commitments) (e.g. strategies adopted by Canada, China, France, Germany, South Korea and the UK); 2) white papers or declarations that provide strategic guidance for future policy action (e.g. Japan, Mexico, Italy, Sweden, USA) (Figure 1).

\section{Figure 1. Timeline of national Artificial Intelligence strategies adoption}

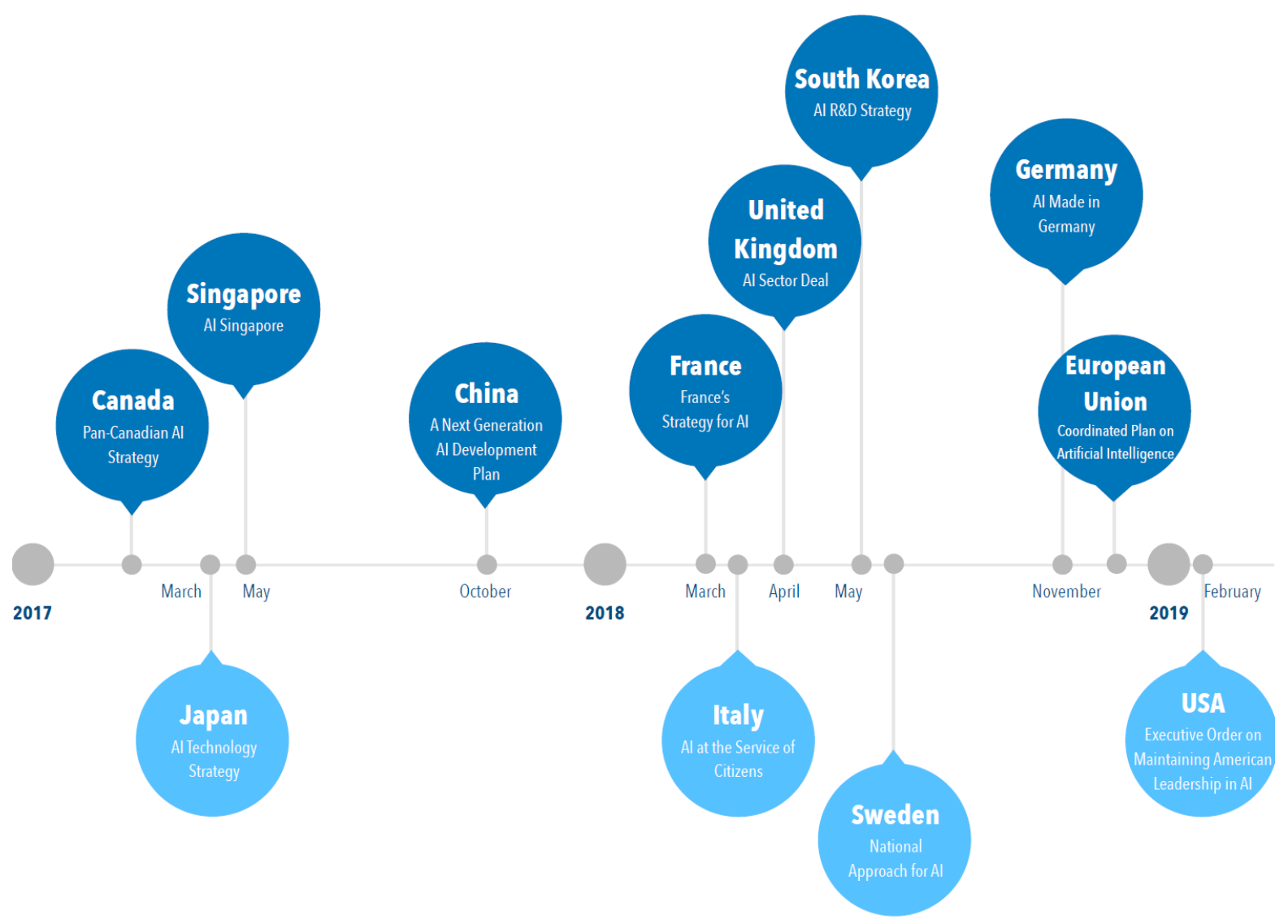


Some countries are currently preparing their strategies while already implementing some AI programmes. In Finland, two interim expert reports -Finland's Age of Artificial Intelligence and Work in the Age of Artificial Intelligence - already provide policy recommendations in different aspects, and have led among others to the creation of the Finnish Centre for AI. In Mexico, the report Towards an AI Strategy in Mexico: Harnessing the AI Revolution, released in June 2018, identifies gaps and opportunities for AI development and provides recommendations for the future elaboration of a national AI Strategy (IA2030Mx, 2018). Similarly, the Austrian Council on Robotics and Artificial Intelligence, set up by the Federal Ministry for Transport, Innovation and Technology, has recently released a white paper with policy recommendations for the future Robotics and AI strategy (ACRAI, 2018). Before issuing the Executive Order on Maintaining American Leadership in Artificial Intelligence in February 2019, the US had already released in 2016 the National Artificial Intelligence Research and Development Strategic Plan, setting a range of priorities for federally-funded research, including developing methods for humanAI collaboration, understanding and addressing the ethical, legal and societal implications of AI, and ensuring the safety and security of AI systems. The Plan was accompanied by the report Preparing for the Future of Artificial Intelligence (National Science and Technology Council, 2016).

AI strategies also differ in terms of their stated objectives and relative weight given to each of those objectives (Table 2) (Dutton, Barron and Boskovic, 2018). Common objectives across most AI strategies are:

- Strengthen research in AI (AI research in Table 2), for example by creating new research centres or devoting specific funding for AI research programmes. The AI strategies of Canada, Germany and South Korea put particular emphasis on actions in this area, with the objective of becoming international leaders in AI research. The Pan-Canadian Artificial Intelligence Strategy, for example, aims to build an AI research community network by funding three centres of excellence in AI research and innovation, located in Edmonton, Montreal and Toronto (CIFAR, 2017). The strategy of South Korea also establishes the creation of new AI research centres focused on integrating AI into research in robotics, bioscience, machinery and automobiles, among others.

- Develop AI talent, through the creation of $\mathrm{AI}$ master or $\mathrm{PhD}$ programmes, and initiatives to attract, retain and train domestic and international AI talent. France and Canada created AI Chairs Programmes to attract and retain top researchers, and to train young researchers (CIFAR, 2017).The AI Sector Deal in the UK supports AI fellowship programs, government funded $\mathrm{PhDs}$, and industry funded masters (GOV.UK, 2018). The Artificial Intelligence Technology Strategy in Japan p plans to tackle the shortage of AI talent by creating new programmes and providing higher salaries to researchers (NEDO, 2017).

- Support businesses develop and adopt AI applications (AI development and adoption by business), for instance by providing specific funding for AI start-ups and SMEs and promoting the creation of AI clusters. The US Executive Order on Maintaining American Leadership in Artificial Intelligence highlights the need to develop standards and reduce barriers to testing and deployment of AI technologies, in order to support new AI-related industries and AI industry adoption. The UK AI Sector Deal also adopts measures for AI diffusion, including by investing in high potential AI business through the Industrial Strategy Challenge Fund competition and the British Business Bank's venture capital programmes (GOV.UK, 2018). The 
Artificial Intelligence Technology Strategy of Japan sets up roadmap, to support the diffusion of AI in the health, welfare and mobility sectors (NEDO, 2017).

- Develop standards for the ethical use of AI (Ethical use of AI), by the creation of expert councils or committees and funding projects to ensure the ethical and transparent development of AI. The Swedish National Approach to AI emphasises the need for appropriate frameworks to ensure an ethical, safe, secure and sustainable use of AI developments, particularly for AI algorithms used by the public sector (Government Offices of Sweden, 2018). The French AI Strategy aims to develop an ethical framework by means of a group of international independent experts, following the model of the IPCC (Intergovernmental Panel on Climate Change), while the AI made in Germany strategy aims to establish an AI Observatory to ensure a sustainable development of AI and initiate a European and transatlantic dialogue on the human-centred use of AI in the world of work (BMWI, 2018). The Canadian strategy funds AI \& Society Workshops that bring together international experts to explore the ethical as well as the wider economic, societal and legal implications of AI (CIFAR, 2019).

Less widely set objectives explicitly discussed in AI strategies include:

- Support responsible data access and sharing (Data access and sharing in Table 2). AI strategies of France, Italy, Sweden and the UK introduce policy actions in the field of data access, covering aspects that range from open data incentives, to privacy protection and cybersecurity. The UK AI Sector Deal sets the objective of exploring fair, equitable and secure data sharing frameworks such as Data Trusts mechanisms where parties have defined rights and responsibilities with respect to shared data. It also establishes the creation of a new Centre for Data Ethics and Innovation (GOV.UK, 2018). The French AI Strategy promotes the creation of sector-specific platforms to compile and share data, provide access to large-scale computing infrastructures suitable for AI, and facilitate experimentation in controlled environments (AI for humanity, 2018).

- Support AI for inclusiveness and sustainable development (Inclusive and sustainable AI). France, Germany and the UK incorporate inclusion objectives into their AI strategies to ensure diversity in the AI talent pool, notably fostering the participation of women and minority groups, as well as promoting AI applications targeted towards social inclusion. The French AI strategy supports AI-based social innovations and the creation of a research centre focusing on AI for the ecological transition (AI for humanity, 2018). The AI made in Germany strategy supports broad societal dialogue around AI issues and provides funding for the development of innovative AI applications that support social inclusion and cultural participation, and that benefit the environment (BMWI, 2018).

- Foster the use of AI by the government (AI use by government). The Italian White Paper Artificial Intelligence at the Service of Citizens focuses on the integration of $\mathrm{AI}$ in government services, emphasising the range of challenges that need to be addressed for instance in the area of skills, use of data and ethics (AGID, 2018). The AI strategy of China also includes the objective of implementing AI to improve government efficiency and service provision. The AI Sector Deal in the UK commits the creation of a GovTech Fund that will support tech businesses to provide the government with innovative solutions for more efficient public services. The German strategy recognises the need of building up the AI expertise of the public administration. 
- Strengthen skills of the labour force (labour force skills). Supporting individuals develop new skills for the digital age is a key axis of the AI strategies of France, Germany and the USA. The provision of vocational or retraining programmes (e.g. to facilitate human-machine interactions), among others, are aimed at improving future working conditions in the context of increased automation.

Overall, the strategies adopted by France, Germany and the UK, and the Communication from the European Commission, are among the most comprehensive, including practically all of the areas presented above. Some strategies include some other objectives. The US Executive Order on Maintaining American Leadership in Artificial Intelligence of February 2019 highlights the need of increasing trust of the population in AI technologies and protecting the country's AI technology base (The White House, 2019). Some, such as the Chinese strategy, also include commitments of investments in infrastructure, such as highperformance computing and fifth generation mobile communication $(5 \mathrm{G})$ systems.

AI strategies have often been developed through an extensive process of consultation with experts and stakeholders. The AI Sector Deal in the UK, developed jointly with industry, specifies government and industry commitments and areas of action to support AI, and builds on the recommendations of the independent AI review Growing the artificial intelligence industry in the UK (Hall and Pesenti, 2017). Similarly, the French strategy largely builds on the expert report For a meaningful artificial intelligence (Villani et al., 2018). A high-level expert groups on AI is currently tasked with monitoring the implementation of the European Commission's Communication on Artificial Intelligence for Europe, as well as developing AI ethics guidelines and proposing policy recommendations. In Germany, a commission was set up in June 2018 to investigate the effects of AI on society and is mandated to give precise recommendations by 2020 (AI Hub Europe, 2018).

AI forums or platforms have also been created in some countries to encourage different stakeholders to collaboratively design roadmaps and engage in strategic planning regarding AI. The Artificial Intelligence Forum in New Zealand was launched in 2017, and brings together AI-related technology innovators, investor groups, businesses, entrepreneurs, academia and government to identify and support AI opportunities in the country. It engages in research that provides insights and information to lead the debate about the opportunities, challenges and potential impacts of AI in the country. Its latest report Artificial Intelligence: Shaping a Future in New Zealand includes a range of policy recommendations (AI Forum, 2018). A similar example is the Learning Systems Platform in Germany (Lernende Systeme, 2018).

Cross-country cooperation to address AI challenges through joint action and investments is also in the rise. In April 2018, European member states signed a Declaration of Cooperation on Artificial Intelligence. Within this framework, France and Germany have already set specific plans to create a joint research and development network based on existing structures and the particular skills possessed by each of the two countries. Key areas of cooperation will be basic research, the transfer of research findings to business, and the development of regulatory approaches and ethical standards. In May 2018, the declaration on AI in the Nordic-Baltic Region, signed by Denmark, Estonia, Finland, Faroe Islands, Iceland, Latvia, Lithuania, Norway, Sweden and the Aland Islands, set the objective of collaborating in different areas to 'develop and promote the use of AI to serve humans better' (Nordic Council of Ministers, 2018). 
Table 2. Overview of national Artificial Intelligence strategies, by objective

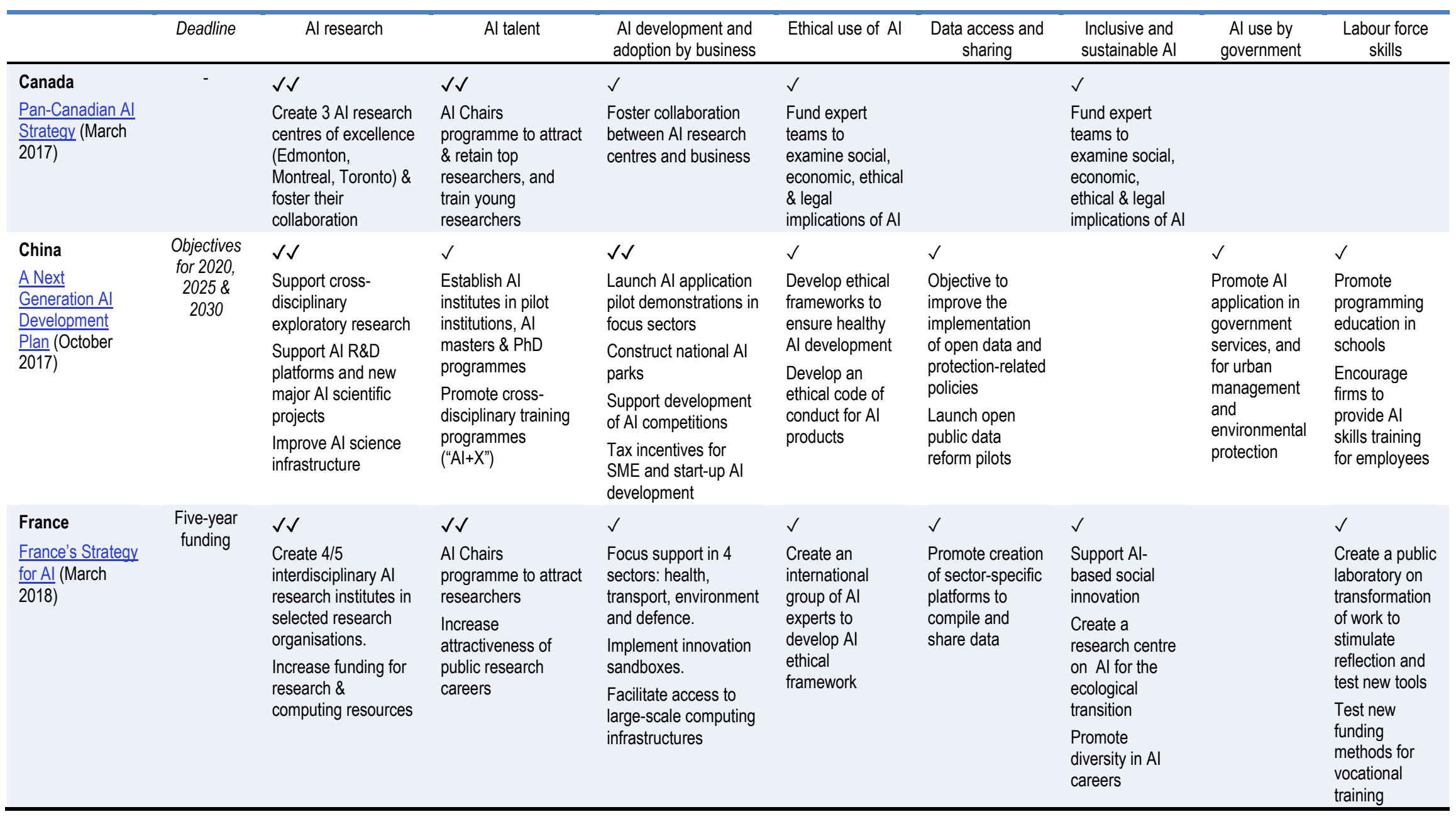


Table 2. Overview of national Artificial Intelligence strategies, by objective

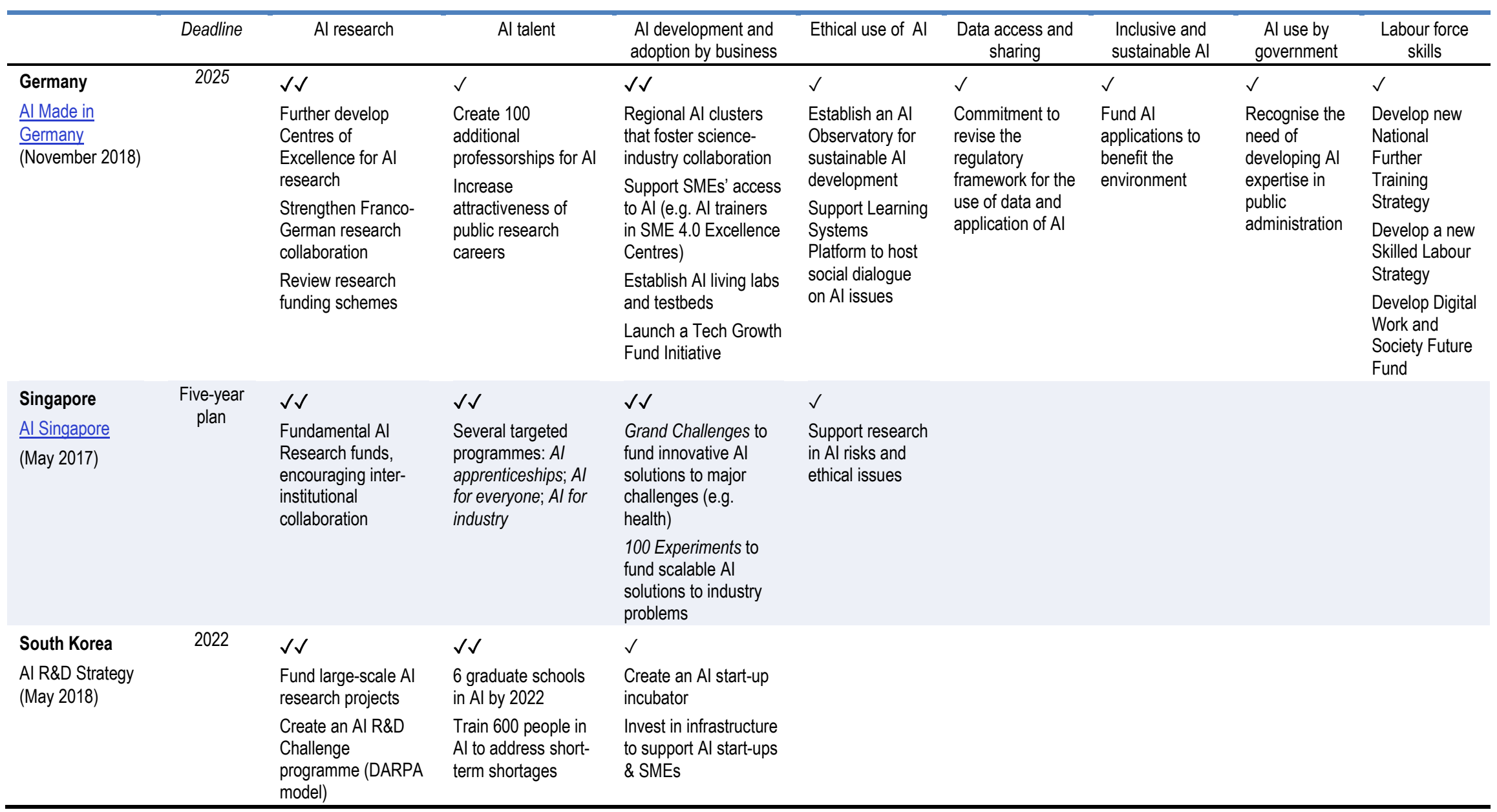

OECD SCIENCE, TECHNOLOGY AND INDUSTRY POLICY PAPERS 
Table 2. Overview of national Artificial Intelligence strategies, by objective

\begin{tabular}{|c|c|c|c|c|c|c|c|c|c|}
\hline & Deadline & Al research & Al talent & $\begin{array}{l}\text { Al development and } \\
\text { adoption by business }\end{array}$ & Ethical use of $\mathrm{Al}$ & $\begin{array}{l}\text { Data access and } \\
\text { sharing }\end{array}$ & $\begin{array}{l}\text { Inclusive and } \\
\text { sustainable Al }\end{array}$ & $\begin{array}{l}\text { Al use by } \\
\text { government }\end{array}$ & $\begin{array}{l}\text { Labour force } \\
\text { skills }\end{array}$ \\
\hline United Kingdom & 2027 & $\checkmark \checkmark$ & $\checkmark \checkmark$ & $\checkmark \checkmark$ & $\checkmark$ & $\checkmark$ & $\checkmark$ & $\checkmark$ & $\checkmark$ \\
\hline \multirow[t]{3}{*}{$\frac{\text { Al Sector Deal }}{\text { (April 2018) }}$} & & $\begin{array}{l}\text { Increase EPSRC } \\
\text { funding to data } \\
\text { science \& Al } \\
\text { research (grants, }\end{array}$ & $\begin{array}{l}\text { Special visas for } \\
\text { exceptional Al talent } \\
\text { Turing Fellowship } \\
\text { programme }\end{array}$ & \multirow{2}{*}{$\begin{array}{l}\text { Support application of } \\
\text { Al in services sectors } \\
\text { (e.g. create Next } \\
\text { Generation Services } \\
\text { Industrial Strategy } \\
\text { Challenge) }\end{array}$} & \multirow[t]{3}{*}{$\begin{array}{l}\text { Establish a } \\
\text { Centre for Data } \\
\text { Ethics and } \\
\text { Innovation }\end{array}$} & \multirow[t]{3}{*}{$\begin{array}{l}\text { Explore new data } \\
\text { sharing } \\
\text { frameworks, e.g. } \\
\text { Data Trusts }\end{array}$} & \multirow[t]{3}{*}{$\begin{array}{l}\text { Commitment to } \\
\text { promote diversity } \\
\text { in Al workforce }\end{array}$} & \multirow{3}{*}{$\begin{array}{l}\text { Create a } \\
\text { GovTech } \\
\text { Fund to } \\
\text { support } \\
\text { innovative } \\
\text { tech solutions } \\
\text { for more } \\
\text { efficient public } \\
\text { services }\end{array}$} & $\begin{array}{l}\text { Improve } \\
\text { technical } \\
\text { education \& } \\
\text { STEM skills }\end{array}$ \\
\hline & & $\begin{array}{l}\text { funding for Alan } \\
\text { Turing Institute) }\end{array}$ & $\begin{array}{l}200 \text { additional } \mathrm{Al} \\
\text { doctoral }\end{array}$ & & & & & & $\begin{array}{l}\text { Create new } \\
\text { National }\end{array}$ \\
\hline & & & & $\begin{array}{l}\text { Support clusters (e.g. } \\
\text { invest in Tech City UK } \\
\text { \& digital } \\
\text { infrastructure) }\end{array}$ & & & & & $\begin{array}{l}\text { Create a } \\
\text { National } \\
\text { College of } \\
\text { Digital Skills }\end{array}$ \\
\hline
\end{tabular}

Note: Ticks $(\checkmark)$ appearing in the table are aimed at illustrating the relevant weight of each of areas of action or objectives within each country AI strategy. A double tick $(\checkmark \checkmark)$ indicates that the objective is a core pillar of the strategy, and that specific actions (and often funding) is allocated to achieve them. A single tick $(\checkmark)$ indicates that the topics are addressed in the strategy but do not constitute its main focus, or are included as areas of future focus.

Source: Dutton, Barron and Boskovic, 2018; CIFAR, 2017; Tian Wen, 2018; AI for humanity, 2017; BMWI, 2018; AI Singapore, 2019; GOV.UK, 2018. 


\subsection{Science, technology and innovation (STI) strategies}

OECD countries all have one or more strategies for science, technology and innovation (STI) (OECD, 2016a). In some cases, digital transformation appears at the heart of STI strategic orientation, as a factor posing both challenges and opportunities for innovation. The New High Tech Strategy in Germany, is one of such cases. It identifies "digital economy and society" as a key priority for research and innovation. This includes supporting science and industry in implementing Industry 4.0 technologies, as well as smart services, big data applications (particularly focusing on SMEs), cloud computing, digital networks, digital science, digital education, and digital life environments (Federal Ministry of Education and Research, 2017).

The $5^{\text {th }}$ Science and Technology Basic Plan in Japan emphasizes the importance of realizing a "Society 5.0", also defined as a "super smart society"2. The plan places the development cutting-edge information and communication technologies (ICTs) and the Internet of Things as a top S\&T policy priority. Consideration is also given to developing AI further, minimising risks and setting the limits of automated decision making (Council for Science, Technology and Innovation, 2015).

In France Europe 2020: A strategic Agenda for Research, Technology Transfer and Innovation, research is viewed as key to address the main emerging scientific, technological, economic and social challenges and to foster competitiveness in the digital era. Main priorities include strengthening research in breakthrough digital technologies and investing in digital training and infrastructures (Ministère de l'Education nationale, de l'Enseignement supérieur et de la Recherche, 2013).

Digitalization-related objectives are also at the core of Smart Specialisation Strategies in some countries. It is the case of Slovenia, which identifies Industry 4.0 is one of the three key priority areas, highlighting the need of digitalising production processes and applying of a range of enabling technologies (e.g. robotics, nanotechnologies, modern production technologies for materials) in specific priority areas (e.g. smart buildings, circular economy, mobility) (Government Office for Development and European Cohesion Policy, 2017). Similarly, the Estonian Research and Development and Innovation Strategy 20142020 "Knowledge-based Estonia" aims to increase the knowledge-intensity and competitiveness of the economy. ICTs (e.g. the use of ICT in industry, cybersecurity, software development) are identified as one of three key priority areas for investment in research, development and innovation (RDI) (Ministry of Education and Research, 2014).

Several countries have established mechanisms to ensure the coordination of policies for the digital transformation across different policy areas (Box 2).

2 The Plan defines the "super smart society" as a society that is capable of providing the necessary goods and services to the people who need them at the required time and in just the right amount; a society that is able to respond precisely to a wide variety of social needs; a society in which all kinds of people can readily obtain high-quality services, overcome differences of age, gender, region, and language, and live vigorous and comfortable lives. 


\section{Box 2. Strategic policy coordination}

Several countries have established mechanisms to ensure the coordination of policies for the digital transformation across different policy areas, including innovation:

- In Korea, the Presidential Committee on the Fourth Industrial Revolution, chaired by the CEO of IT Ventures, gathers the ministers of science and ICT, industry, labour, and SMEs and startups, as well as 19 specialists from academy, industry and public institutions. Launched in 2017, its main mission is to develop a comprehensive and human-centric national plan to address the challenges of the $4^{\text {th }}$ industrial revolution, with three policy priorities: i) establish a world-class infrastructure for intelligent IT and basic science; ii) promote the application of intelligent IT in all industries and public services; and iii) reform and tailor education, employment and welfare services in order to ensure that all citizens are able to enjoy the benefits of digital transformation. The Committee also coordinates the action plans and policies between ministries, and monitors and evaluates the implementation of relevant policies and projects (Ministry of Science, ICT and Future Planning, 2017a).

- In Chile, a Committee for Digital Transformation has been recently launched to promote the use of digital technologies in the private and public sectors and increase the competitiveness of the Chilean economy in global markets. The committee aims to facilitate the digital transformation by identifying areas that require regulatory reforms, developing standards and strengthening skills, among others (Comité de Transformación Digital, 2017).

- The Digital roadmap Austria, released in 2016, is an overarching strategy that coordinates and ensures the timely adaptation of strategies for the digital transformation that already exist or are in development, such as the Broadband Strategy 2020, the Open Innovation Strategy, and the Creative Industry Strategy. Its elaboration brought together policy makers in different policy areas, businesses, employer's associations, science and research representatives and the overall civil society, in an effort to jointly shape the process of digital transformation in the country. It identifies 150 specific measures in 12 fields of action, including education, research and innovation, business, environment, transport and media. An annual Digital Summit assesses the latest trends and draw conclusions regarding the focus of future activities (Federal Chancellery and Federal Ministry of Science, Research and Business, 2016). 


\subsection{Industrial policy strategies}

Some countries have developed industrial policies ${ }^{3}$ (as part of STI strategies or as strategies on their own) providing support for business innovation, sometimes focusing on specific technology areas or sectors (often but not exclusively in manufacturing) (OECD, 2016b). Concerns about the decaying capacity of manufacturing sectors to remain a source of growth as well as prospects for the advent of a fourth industrial revolution as a result of emerging technology breakthroughs are behind this renewed interest in industrial policy (OECD, 2017a). The Digitising European Industry (DEI) initiative, launched in 2016 by the European Commission, has also requested EU member states to adopt their own national initiatives to digitise industry (European Commission, 2018b).

Industrial policies aim at ensuring that national economies develop competitive advantages in emerging sectors and that domestic firms can (continue to) perform high-value added activities in value chains. Fostering digital innovation and the adoption of new digital technologies by industry (particularly traditional sectors and SMEs) are often at the core of these initiatives. They also often set some of the following objectives (Table 3) (OECD, 2016a; OECD, 2016b):

- support the development of cutting-edge technologies (particularly at the upstream stage of development);

- facilitate innovators' access to applied research centres and demonstration facilities (e.g. test beds, pilot lines and factory demonstrators), to accelerate the transition of innovations from the laboratory to production;

- promote interaction and cooperation among different innovation actors (e.g. universities, research centres, large firms and SMEs), with a focus on interdisciplinary and cross-sectoral collaborations for innovation.

- improve framework conditions for innovation, including by addressing barriers faced by innovative entrepreneurs and strengthening digital skills.

Strategies also have singularities. For instance, the strategies of France and Portugal establish as objective increasing the international visibility of innovative technical solutions created in the country.

Some countries have implemented strategies focused on specific sectors or technologies. Made in China 2025, aimed to transform and upgrade the Chinese manufacturing system by enhancing innovation, product quality and environmental sustainability, focuses on 10 key technology areas: new generation information technology, computerised machines and robots; aerospace and aeronautical equipment; maritime equipment and high-tech shipping; advanced railway transportation equipment; new energy and energy-saving vehicles; energy equipment; agricultural machines; new materials and biopharma; and high-tech medical devices (OECD, 2017a). More recently, China has released the Internet Plus action plan, which aims to increase the competitiveness of Chinese firms through the application of digital technologies (AI and big data, among others) in traditional and emerging industries (EC/OECD, 2018a).

3 Industrial policies are defined as "any type of intervention or government policy that attempts to improve the business environment or to alter the structure of economic activity toward sectors, technologies or tasks that are expected to offer better prospects for economic growth or societal welfare that would occur in the absence of such intervention" (Warwick, 2013). 
The strategy New Industrial France also aims to modernise the country's production system, and identifies 9 industrial solutions to respond to key economic and social challenges: the data economy, smart objects, digital trust, smart food production, new resources, sustainable cities, eco-mobility, medicine of the future and transport of tomorrow (Ministère de l'Économie et des Finances, 2017).

\section{Table 3. Examples of industrial strategies with a digital focus}

\begin{tabular}{|c|c|}
\hline & Main objectives \\
\hline $\begin{array}{l}\text { Smart Industries Strategic } \\
\text { Programme (Chile) }\end{array}$ & $\begin{array}{l}\text { - Facilitate the digital transformation of industry, by providing tailored solutions to the } \\
\text { needs of different sectors (including traditional ones, e.g. mining, agriculture and fishing). } \\
\text { - Enhance the capacities of the digital sectors in the country, so as to make Chile a } \\
\text { regional leader in those sectors and better match the offer and demand of new } \\
\text { technologies at national level }\end{array}$ \\
\hline$\frac{\text { New Industrial France }}{\text { (France) }}$ & $\begin{array}{l}\text { - } \quad \text { Develop cutting-edge technologies to ensure France remains competitive in emerging } \\
\text { - } \quad \text { Hectors and ensure that those technologies are available across the economy; } \\
\text { - } \quad \text { Train employees to perform new tasks and jobs } \\
\text { - } \quad \text { Provide visibility to innovative French technical solutions both in France and abroad; } \\
\text { - } \quad \text { Strengthen international cooperation to support joint technological and training efforts }\end{array}$ \\
\hline$\frac{\text { National Plan Industria } 4.0}{\text { (Italy) }}$ & $\begin{array}{l}\text { - Promote private investments in Industry } 4.0 \text { and in research and innovation, particularly } \\
\text { in advanced manufacturing solutions, additive manufacturing, augmented reality, } \\
\text { simulation, horizontal and vertical integration, industrial Internet, cloud, cybersecurity, } \\
\text { and big data and analytics; } \\
\text { - } \quad \text { Strengthen skills for the digital economy; } \\
\text { - } \quad \text { Generate interest on Industry } 4.0 \text { opportunities and create the public-private governance }\end{array}$ \\
\hline$\frac{\text { Industry } 4.0}{\text { (Portugal) }}$ & $\begin{array}{l}\text { - Provide businesses with knowledge and necessary tools for their successful digital } \\
\text { transformation; } \\
\text { - } \quad \text { Promote national technological solutions abroad; } \\
\text { - } \quad \text { Make the country an attractive location for Industry } 4.0 \text { investments. }\end{array}$ \\
\hline$\frac{\text { Connected Industry } 4.0}{\text { (Spain) }}$ & $\begin{array}{l}\text { - } \quad \text { Ensure knowledge and skills development for Industry 4.0, mainly through awareness } \\
\text { raising activities and training; } \\
\text { - } \quad \text { Foster multidisciplinary collaboration, by facilitating the creation of collaborative } \\
\text { environments and platforms; } \\
\text { - Encourage the development of digital enablers by providing support to technology } \\
\text { companies; } \\
\text { - } \quad \begin{array}{l}\text { Promote the adoption of digital technologies by industry, particularly SMEs, by providing } \\
\text { funding for digitalisation projects and advice }\end{array}\end{array}$ \\
\hline$\frac{\text { Smart Industry strategy }}{\text { (Sweden) }}$ & $\begin{array}{l}\text { One of its four focus areas is fostering Industry 4.0, and includes the following objectives: } \\
\text { - Stimulate the development, spread and use of the digital technologies that have the gre- } \\
\text { atest potential to lead the industrial sector's transformation; } \\
\text { - } \quad \text { Encourage new business and organisational models in order to tap the potential of the } \\
\text { new technologies; } \\
\text { - } \quad \text { Meet new knowledge requirements that are brought about by digital development; } \\
\text { - }\end{array}$ \\
\hline
\end{tabular}

Note: The Made Different Digital Wallonia is integrated in the Plan Marshall 4.0 for Wallonia. Industry 4.0 strategy in Portugal is integrated into the National Strategy for the Digitalization of the Economy. Source: Digital Wallonia (2017), CORFO (2017), Ministère de l'Économie et des Finances (2017), Ministero dello Sviluppo Economico (2017), IAPMEI (2018), Ministerio de Economía, Industria y Competitividad (2017), Government Offices of Sweden (2016). 
The Robot Strategy in Japan is an example of technology-specific strategy. It aims to expand the use of advanced robotics across Japanese industry. Its three main pillars are enhancing innovation in robotics by investing in infrastructure and human resources; increasing the use and diffusion of robots across all sectors and firms, including SMEs; and participating in the establishment of global standards and safety rules in the field of robotics (e.g. standards for personal care robots) (Ministry of Economy and Trade, 2015).

To guide the process of developing and implementing strategies and concrete actions for industry 4.0, a number of governments, often jointly with industry, have recently established new platforms or forums for discussion that gather all key stakeholders (from industry, academia, civil society, and government). Such platforms encourage debates around the economic and social impacts of digital transformation of industry, and aim both to create a shared vision and to provide balanced policy recommendations (Box 3).

\section{Box 3. Industry 4.0: Forums or platforms for strategic planning}

A number of platforms have been created to encourage all stakeholders to collaboratively design roadmaps and engage in strategic planning for the digital transformation:

- The Plattform Industrie 4.0 in Germany gathers business representatives, policy makers and experts from science, associations and trade unions. The platform aims to identify all relevant trends in the manufacturing sector and combine them to produce a common overall understanding of Industry 4.0 and provide policy recommendations. The platform's technical work is carried out in thematic working groups, one of which focuses on identifying the research areas needed to advance Industry 4.0 in Germany. The platform does not realise activities in the market (e.g. demonstration centres, research projects or company-led projects) but proactively supports them (Federal Ministry for Economic Affairs and Energy, 2017a).

- The Plattform Industrie 4.0 Austria gathers actors from industry and science, regional and national policy makers, associations, trade unions and NGOs to accompany the processes of change driven by the digital transformation, and provide knowledge and services on Industry 4.0 to companies, academia, research organisations and to the general public. It defines the fields of action and provides advice to Austrian policy makers to develop joint strategies to fully benefit from Industry 4.0. It is organised around seven working groups (Boog et al., 2019).

- The Regional Platform I 4.0 in Upper Austria is an industry-driven platform initiated in bottom-up mode in the framework of the Upper Austrian Strategic Economic and Research Program "Innovative Upper Austria 2020". Its main functions are: enabling high-level discussions on Industry 4.0; providing and diffusing information; raising awareness and orientation; offering participative planning procedures for future activities; defining goals, tasks and proposals for (short-term) practical implementation of measures (action plans and roadmaps); and providing services to industrial companies (Rhomberg et al., forthcoming).

- In Turkey, the Platform of Digital Transformation in Industry brings together all relevant stakeholders to identify strategies that ensure a successful digital transformation of industry. Organised in working groups, the platform has two main goals: i) strengthening the capacity of industry to design and produce hightech products; ii) enhancing digital skills (EC/OECD, 2018b). 


\section{Innovation policy initiatives for the digital age}

Countries have also started to implement specific initiatives to ensure a successful transition of their innovation ecosystems to the digital economy. This section provides an overview of recent and most innovative policy approaches taken by countries to 1) enhance digital technology adoption and diffusion, particularly among SMEs; 2) promote collaborative digital innovation ecosystems; 3) support research and innovation in key digital sectors and technologies; and 4) support digital entrepreneurship. Other key objectives of initiatives that are not analysed in detail in this paper include promoting investments in digital skills and competences, as well as establishing favourable general framework conditions for innovation.

\subsection{Initiatives for digital technology adoption and diffusion}

New digital technologies are developing quickly, but do not diffuse evenly across the economy. Well-known challenges that have affected technology adoption in the past and remain relevant at present - such as lack of information, skills, expertise, resources or trust in new technologies - contribute to widening productivity gaps between leading and lagging firms in the digital era, with negative impacts on well-being and growth. Initiatives supporting economy-wide diffusion and adoption of digital technologies thus become the backbone of innovation policy mixes aimed at promoting inclusive innovation-led growth (i.e. where all actors can participate in and benefit from digital innovation).

Governments are experimenting with novel policy approaches to furthering digital technology adoption and diffusion. These initiatives aim in particular at facilitating: 1) awareness raising and capacity building; 2) digital technology investments; and 3) the demonstration and testing of new technologies. Some of these initiatives combine several of the instruments presented below. For instance, German SME 4.0 Competence Centres provide awareness raising support and training about digitalisation, opportunities to access demonstrations of new technologies, and opportunities for networking.

\section{(1) Awareness raising and capacity building}

Awareness-raising schemes are deployed in many countries to inform firms and entrepreneurs about the opportunities that digital technologies offer. Innovative approaches include the following:

- On line of virtual maps developed by France, Germany and Japan, which display domestic SMEs in different sectors engaged in Industry 4.0 transformations in order to inspire similar firms to engage in the digital transformation. Such maps allow sharing first-hand experiences of the benefits and challenges faced by firms, and how these were addressed (Alliance Industrie du Futur, 2016; Plattform Industrie 4.0, 2015; Robot Revolution Initiative, 2016).

- Watify is an online platform set up by the European Commission where entrepreneurs share their experiences regarding the digitalisation of their businesses through video interviews posted online (European Commission, 2017a).

- The annual fair EXPO MiPyme Digital in Colombia exhibits new digital technologies for SMEs with the aim of increasing awareness on how these can help 
grow and expand their activities. Each event has a training programme (e.g. on digital management, digital marketing, e-commerce) delivered through conferences, workshops, debates and advisory services (ENTER.CO, 2017).

- The Smart Tech programme, implemented by the Business Development Bank of Canada, provides SMEs with free online tools, such as guides on how to select and implement the right digital technology and establish social media presence (OECD, 2016b).

Awareness-raising activities are typically accompanied by more tailored, often sectorspecific business advisory support to enhance businesses' capacities to successfully adopt digital technologies. For example:

- The Digital Extension Centre in Chile provides technical assistance to SMEs in the agri-food sector to improve their competitiveness by digitalising production processes. Support consists of assessing the firm's capabilities, identifying the best digital technology solutions for each case, and helping deploy the solutions and ensure their best use (Ministerio de Economía, Fomento y Turismo, 2019).

- The SME Digital programme in Austria provides tailored education and training to strengthen the digital skills of SMEs (BMDW, 2018). Similarly, the CAP'TRONIC programme in France provides technical seminars, training, counselling services and expert support to help SMEs employ digital solutions and embed software in their products (CAP'TRONIC, 2017).

- The Trusted Cloud in Germany promotes the use of cloud among businesses, particularly SMEs, by informing them about the possible cloud applications within their businesses, and identify trusted cloud service providers (Federal Ministry for Economic Affairs and Energy, 2017b).

- The "SMEs Go Digital" programme in Singapore has established SME Digital Tech Hubs that offer grants to facilitate SMEs' access to easy-to-use pre-approved technology solutions; technical support for adopting more advanced technologies; and workshops to enhance their digital capabilities (IMDA, 2017).

A traditional policy instrument that has been adapted in many countries to address digitalisation challenges are innovation vouchers - small non-repayable grants provided to SMEs to purchase services from public knowledge providers that will help introduce small-scale innovations. For instance, the trading online voucher scheme in Ireland assists SMEs in developing their e-commerce capabilities, providing up to EUR 2500 matched by their own funding (DCCAE, 2018). Service design vouchers for manufacturing SMEs in the Netherlands are an experimental scheme to help these SMEs develop services related to their products, so as to remain competitive in a context of increasing "servitisation of manufacturing" (RVO, 2018). In Wallonia (Belgium), the vouchers for digital transformation cover between $50 \%$ and $75 \%$ of the cost of advisory services aimed at auditing the digital maturity and needs of SMEs and then designing a tailored action plan (Chèques entreprises, 2018). Some European regions have also implemented ICT Innovation Voucher programmes targeted at SMEs that cover ICT services (e.g. ICT design and development, e-Commerce, e-skills, business solutions services, new ICT-based business models) (European Commission, 2017b). 


\section{(2) Financial support for digital technology investments}

Governments have established financial support mechanisms to help cover often largescale infrastructure investments needed for SMEs to fully engage in the digital transformation. In Korea, the SMEs Programme for Smart Manufacturing helps SMEs modernise their production facilities by financing up to $50 \%$ of the costs of digital technology adoption. France has established the Digital Loan scheme to help finance corporate investments for the introduction of digital technologies in firms. Loans range between EUR 200000 and EUR 3 million, and need to be matched with at least equivalent co-funding, to be reimbursed over seven years (Bpifrance, 2018).

\section{(3) Demonstration and testing of new digital technologies}

Some countries have established new facilities to demonstrate or test digital technologies, as a means of increasing adoption. For instance, the SME 4.0 Competence Centres in Germany offer SMEs access to demonstrations of Industry 4.0 technologies and sectorspecific applications (e.g. 3D printing, sensors). These demonstration facilities are often located at universities and allow simulating business and production processes in a realworld environment (Competence Centres, 2018). Pilot factories have also been set up in several Austrian universities (TU Wien, TU Graz and Johannes Kepler University Linz), where SMEs can test new technologies and production processes without having to affect production in their facilities (Mattauch, 2017). The Norwegian Catapult Centers also support the establishment and operation of facilities that offer testing, simulation and visualisation services for businesses (particularly SMEs) and research institutions, at all stages of the innovation process (Norsk Katapult, 2018).

\section{(4) Access to state-of-the-art technologies and expertise}

Some interesting initiatives aim to facilitate early adoption of advanced digital technologies and ensure innovators' access to state-of-the-art facilities. These target the most innovative firms (e.g. small, digital start-ups) by helping them realise their opportunities to innovate in new areas and to be able to compete with larger, global organisations.

Digital Catapult has several such initiatives in place. One is the Dimension Studio, aimed at ensuring that UK businesses have access to volumetric capture technology, which is expected to drive the next generation of immersive experiences and products. Another is the Machine Intelligence Garage programme, which helps businesses access the computation power and expertise they need to develop and build machine learning and AI solutions (Digital Catapult, 2019).

In some European countries, High Performance Computing (HPC) centres have been set up in connection with the Supercomputing Expertise for SME Network programme to facilitate access by industry (especially SMEs) to HPC expertise. They also help disseminate best practices in HPC industrial use (SESAME Net, 2018). 


\subsection{Initiatives for collaborative digital innovation ecosystems}

The relevance to innovation of collaboration among firms and universities, research institutions and in some cases individual inventors is not specific to digital innovation, but collaboration is certainly taking on greater importance in the digital age (see OECD, 2019). The reduced cost of collaboration stemming from digitalisation has not reduced the barriers to collaborating, such as differing regulatory regimes and diverging incentives. Furthermore, with accelerated technological change, rapidly translating research findings into innovative goods and services becomes critical. In this context, countries continue to put emphasis in supporting innovation ecosystems, and increasingly consider new forms of collaboration towards innovation, such as data sharing, crowdsourcing and co-creation.

The innovative policy approaches and instruments to support collaborative digital innovation ecosystems presented in this section are: 1) collaborative research and innovation centres; 2) collaboration facilitators, including intermediary organisations, networks and clusters; 3) crowdsourcing, open challenges and living labs to foster open innovation; and 4) financial support for collaborative R\&D.

\section{(1) Collaborative research and innovation centres}

Several countries have created (networks of) research centres where multi-disciplinary teams of public researchers and businesses work together to address specific technology challenges. These not only provide new spaces for collaboration and co-creation, but also stand out for their innovative organisational structures, often in line with innovative business practices that implement agile methods and create start-up-like environments.

Data61 (CSIRO) is the largest digital $R \& D$ centre in Australia. Its mission is to put Australia at the forefront of data-driven innovation, both by pursuing new-to-the-world fundamental and applied research, and by working collaboratively with other actors in the nation's innovation ecosystem. It has four axes of collaboration:

- collaborations with other CSIRO business units to provide multi-disciplinary R\&D and data science expertise across domains

- collaborations with universities through research partnerships, agreements on strategic joint appointments, and co-funding of PhD students

- collaboration with government in the area of digital service transformation and policy analytics - particularly in the field of open data, acting as trusted advisor and providing technology development, contract $\mathrm{R} \& \mathrm{D}$ assistance and strategic guidance

- collaboration with industry to convert ideas into data-driven businesses, including programmes targeted at SMEs and start-ups, such as in the area of technology licensing, $R \& D$ partnerships, innovation accelerators, and access to expertise.

To increase agility and attract digital talent, Data61 has adopted a "start-up culture" or "market pull" approach: organisational structures are flatter (i.e. with less middle management and higher autonomy of staff) and research leaders are encouraged to experiment with new ideas and to take risks while maintaining full alignment with the strategic goals of the organisation. A "challenge model" also has been introduced to stimulate multidisciplinary teams to address large-scale social and business challenges. Another innovative feature is Data61's mixed funding model, aimed at balancing public and commercial sources of funding to ensure that the organisation does not become a 
"work-for-hire" (consultancy-type) entity. The objective is to attract profitable, highmargin revenues to provide additional capacity to do self-directed fundamental and strategic research (Data61, 2019).

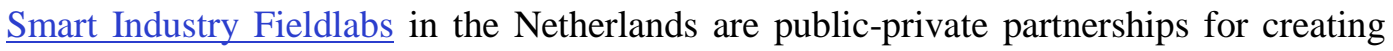
physical or digital spaces for member companies and research institutions to jointly develop, test and implement new smart industry technological solutions (e.g. in the fields of automation, zero defect manufacturing, flexible production, value creation based on big data, 3D printing and robotics). The 32 current field labs typically include users of such solutions, (potential) suppliers and knowledge institutes, and are active in collaborative research, concept validation, prototyping, testing and validation. Field labs ensure an interdisciplinary approach and link research to domains where the Netherlands has specific strengths. They do not have hierarchical structures and follow a project-based approach (Stolwijk and Punter, 2019).

The Manufacturing USA programme has established manufacturing innovation institutes across the United States. Within each institute, manufacturers of all sizes partner with academia and government to share and solve industry-relevant advanced manufacturing technology and workforce challenges, and to build a robust, sustainable national manufacturing $R \& D$ infrastructure so as to enhance industrial competitiveness and economic growth. Each institute has a unique technological concentration and is designed to be a public-private membership organisation that provides vision, leadership and resources to its members. Industry, academia and government partners are benefiting from existing resources, collaborating, and co-investing to nurture manufacturing innovation and accelerate commercialisation (AMNPO, 2018).

The Flanders Make in Belgium is a research centre that collaborates with research labs at all Flemish universities. It was created to support both SMEs and large manufacturing companies with industry-driven, pre-competitive research in four technology domains (power electronics \& energy storage, mechatronics \& design methods, production processes and people-driven system development) in order to foster product and process innovation in three fields (vehicles, machines and factories) (Flanders Make, 2017).

In Ireland, there are currently 10 Technology Centres led by industry that employ highly qualified researchers associated with research institutions to undertake market-focused $R \& D$ for the benefit of industry. The technology centres programme is a joint initiative between Enterprise Ireland and the Industrial Development Authority -the agency responsible for the attraction of FDI in Ireland-that allows companies to work together on research projects with research institutions. Ireland's Centre for Applied AI (CeDAR) is one of those centres (Enterprise Ireland, 2017). Similarly, the Technology Competence Centres in Estonia foster long-term collaboration between universities and businesses to develop new technologies and innovative solutions that are relevant to industry. Two of the six centres focus on digital technologies: the Software Technology and Applications Competence Centre (STAAC) specialises in developing machine learning models and data analytics solutions, and the Eliko Technology Competence Centre specialises in developing new products and services building on the IoT technologies (Estonian Clusters, 2017a). 


\section{(2) Collaboration facilitators: intermediaries, networks and clusters}

\section{Intermediary organisations}

Intermediary organisations connect different actors in innovation ecosystems (innovators, big firms, SMEs, investors, etc.) and facilitate their matching and collaboration for research and innovation.

The Catapult Centres in the United Kingdom are a network of ten not-for-profit, independent physical centres that connect businesses with the country's research and academic communities. Each of them focuses on a strategic technology area in which the United Kingdom has great potential for growth. They offer a space with the facilities and expertise to enable businesses and researchers to collaboratively solve key problems and develop new products and services on a commercial scale. They also help businesses access foreign markets, create and retain high-value jobs, and attract inward investments from global technology businesses. The Digital Catapult in particular focuses on digital innovation, targeting specifically digital manufacturing and creative industries and specialising on a range of technologies, including the IoT, AI and virtual and augmented reality technologies (Digital Catapult, 2019).

Industry Growth Centres in Australia also aim to build stronger industry systems through collaborative, industry-led processes. The six independent, non-for-profit centres focus on increasing collaboration and commercialisation of innovations in specific sectors, and on improving access to global supply chains and international opportunities (Australian Government, 2018).

\section{Physical and digital networks}

Some countries provide support for creating innovation networks that promote interaction and collaboration among actors within and across sectors. The Knowledge Transfer Network, established by Innovative UK, helps linking companies across industries to solve problems and find markets for new ideas, while facilitating access to technical knowledge and innovation capabilities. It also facilitates access to UK and EU calls for public funding that require collaboration among different stakeholders. In 2017, the network organised more than 400 events involving over 20000 participants (Knowledge Transfer Network, 2018).

Digital platforms also facilitate the creation of networks to boost industry-research collaborations. Public research and universities can advertise their inventions, knowledge and capacities, and businesses can post their own needs. The two sides can then interact and agree on deals. Such platforms support small-scale entrepreneurs in particular, by offering them opportunities to identify adequate niche markets. For example, Expert Connect is a searchable database created by Data61 in Australia, which contains profiles of over 45000 research and engineering experts from Australian research organisations (Data61, 2018a, b).

\section{Clusters for digital innovation}

Cluster policies -traditionally used to foster innovation and growth in a specific geographic area- are receiving new impulse in the digital era, with the creation of digital research and innovation hubs. Their objective is promoting partnerships for research and innovation between regional actors in a specific manufacturing sector or technology area, to enhance their competitiveness at the national and international levels and ensure science-industry 
knowledge transfer. Such initiatives often provide funding for collaborative R\&D projects, training and different types of business support services (e.g. for internationalisation of business, finding external partners).

The Digital Hub Initiative in Germany supports the establishment of digital hubs around the country, that would connect German and international start-ups with established companies, researchers and investors in a specific region, following the example of Silicon Valley. Hubs aim to foster networking and cooperation within and between hubs, and are expected to serve as platforms for engaging in dialogue with global market leaders and foreign investors. To facilitate such interactions, the initiative has developed a joint brand ('de:hub') and created a joint Hub Agency. Efforts are currently ongoing to develop an international marketing campaign to build reputation of the hubs abroad, to attract international start-ups, scientists, companies and investors. There are currently hubs in 12 cities, each focusing on a particular industry (e.g. IoT\&Fintech hub in Berlin, Artificial Intelligence hub in Karlsruhe, Digital chemistry and digital health hub in Ludwigshafen/Mannheim) (Federal Ministry for Economic Affairs and Energy, 2017c, 2017d). Also in Germany, It's OWL is a technology and innovation platform in Ostwestfalen-Lippe - a region with a strong industry base in the fields of mechanical engineering, automotive and energy technologies - that gathers companies, universities, and research institutes to develop intelligent products and production processes. One of their key objectives is ensuring technology transfer to SMEs (It's OWL Clustermanagement, 2017).

The Estonian ICT Cluster promotes co-operation among businesses in the ICT and other sectors, to develop new products and solutions. The cluster supports businesses in three areas: internationalisation (e.g. organising business visits and export-related activities, joining international innovation projects); workforce development (e.g. providing training, forecasting the skill needs of the workforce); and co-operation (e.g. supporting research activities among cluster partners and helping to find external partners) (Estonian Clusters, 2018).

Other examples include the Innovation Superclusters Initiative in Canada, the French Cluster for Digital Transformation (Cap Digital) in Paris, the Digital Hub in Dublin (Ireland) and the Cluster Intelligent Factories in Lombardy (Italy) (Government of Canada, 2018; Cap Digital, 2018; Digital Hub, 2017; Associazione Fabbrica Intelligente Lombardia, 2014).

\section{(3) Towards open innovation: Crowdsourcing, open challenges and living labs}

In line with the business trend towards open innovation practices, governments are also exploiting mechanisms such as crowdsourcing, open challenges and living labs to find innovative solutions to pressing challenges and to nurture co-creation. Citizenscience.gov is an initiative designed by the US Government to accelerate the use of crowdsourcing so as to engage the public in addressing social needs and to accelerate innovation. The website also provides a Crowdsourcing and Citizen Science Toolkit that shows how to plan, design and carry out a crowdsourcing or citizen science project, and showcases a number of case studies (CitizenScience.gov, 2018).

Open challenges are also increasingly used to encourage innovation. For example, the Social Challenges Innovation Platform (created with EU Horizon 2020 programme funding) encourages social innovators and entrepreneurs to propose innovative solutions to social and environmental challenges that public authorities, private firms or NGOs aim to solve, and that post in the platform (SocialChallenges.eu, 2018). Pit Stop events, organised 
by Digital Catapult (United Kingdom), encourage open innovation by bringing together large firms, SMEs, start-ups and academics to solve specific technology challenges. Disruptive technology start-ups and other actors able to solve such challenges are identified via online open calls (Digital Catapult, 2019).

Living labs are defined as "user-centred, open innovation ecosystems, integrating research and innovation processes in real life communities and settings" (ENoLL, 2018). They are localised areas of experimentation within urban environments, in which stakeholders collaboratively develop new technology-enabled solutions. Smart Kalasatama in Helsinki is an example of a living lab that has achieved high citizen engagement in the co-creation of new urban services enabled by digital technologies and data (Mustonen, 2016). In Antwerp (Belgium), a "City of Things" is being developed through installation of a dense network of smart sensors and wireless gateways in buildings, streets and objects. Collected data can be used by companies to build innovative smart applications (Department of Economy, Science and Innovation, 2017).

\section{(4) Financial support for collaborative $R \& D$}

Other instruments used to encourage collaboration include conditional grants for collaborative R\&D and innovation projects, such as the MADE Digital ${ }^{4}$ initiative in Denmark, funded by the Innovation Fund Denmark. The programme funds applied research projects developed in cooperation between Danish universities, experts from research and technology organisations (RTOs) and manufacturing companies (both large firms and SMEs) to develop and implement tailored digital solutions to the needs of those companies (MADE, 2018). Stimulating research collaboration is also one of the key objectives of the Research-Create-Innovate programme in Greece, which provides grants for research and innovation in key areas in which ICT technologies are key enablers, to strengthen the country's competitiveness (Gongolidis, 2019). The Industrial Strategy Challenge Fund in the United Kingdom supports science-industry collaboration to jointly find solutions to major societal, environmental and industrial challenges identified by the government together with industry and academia (GOV.UK, 2017).

\footnotetext{
$4 \quad$ MADE stands for Manufacturing Academy of Denmark.
} 


\subsection{Initiatives to support research and innovation in digital technologies}

Countries with strong capacities to develop and adopt cutting-edge digital technologies will be better positioned to have a successful transition to a digital economy. Countries are thus investing in supporting research and innovation activities in key areas. While there is some consensus internationally regarding the identification of key emerging (including digital) technologies (e.g. Internet of Things, Artificial Intelligence, additive manufacturing), research priorities vary across countries depending on their research and industrial strengths. Research domains are also increasingly multidisciplinary and in constant evolution. In addition, it is the combination and integration (also called 'convergence') of different technologies that is likely to enable the development of new applications (OECD, 2017a). This makes it challenging for policy makers to define specific priority research domains.

This section presents innovative policy initiatives implemented in different countries to 1) foster experimentation in emerging areas enabled by digital innovation, and 2) promote research and innovation activities in through grants and other financial incentives. The last section presents initiatives specifically dedicated to supporting research and innovation in the field of AI and big data.

\section{(1) Enabling experimentation: Test beds and regulatory sandboxes}

Test beds are testing environments where new technology developments can be tested in controlled but near to real-world conditions. They are critical for research and innovation in areas such as autonomous driving, and allow accelerating the development and adoption of new digital technologies. In Finland, a number of test beds are being established for the open development of transport and mobility solutions, such as automated driving, mobilityas-a-service, and intelligent traffic infrastructures (Team Finland, 2017). Many other countries have established (or are currently in the process of establishing) testing grounds for self-driving vehicles, including Austria (ALP.Lab, DigiTrans), Germany (A9 Digitale Autobahn) and Sweden (AstraZero) (BMBWF, MBVIT and BMDW, 2018).

In the United Kingdom, a test beds programme was introduced in 2016 by the National Health Service (NHS) in partnership with industry. Such test beds allow testing innovations (e.g. combinations of new digital devices such as sensors, monitors, wearables with data analysis) and new approaches to service delivery facilitated by digital technologies, with the objective of assessing their efficiency and identifying action needed to improve them. Successful innovations are then made available to the NHS and care organisations around the country. There are currently five health and care test beds and two IoT test beds. In view of successful outcomes, a second wave of test beds has been launched (NHS England, 2018). Similar examples include the Digital Health Test Beds programme recently deployed in Australia (Australian Government, 2018) and the Nordic Test Beds (NoTeB) created in collaboration between hospitals and health innovation centres in Denmark, Finland, Norway and Sweden (NoTeB, 2019).

Regulatory sandboxes provide a limited form of regulatory waiver, or flexibility for firms to test new products or business models with reduced regulatory requirements, while preserving some safeguards (e.g. to ensure appropriate consumer protection) [see DSTI/CDEP/GD/RD(2018)1]. Sandboxes help identify and better respond to regulatory breaches, and enhance regulatory flexibility. They are particularly relevant in highly regulated industries, such as financial services (OECD, 2018), transport (ITF, 2015), energy (OECD/IEA, 2017) and health (OECD, 2017c). 
The Financial Conduct Authority in the United Kingdom pioneered this approach with the launch of the fintech regulatory sandbox to encourage innovation in the field of financial technology. The sandbox provides the conditions for businesses to test innovative products and services in a controlled environment without incurring the regulatory consequences of pilot projects (FCA, 2015). Other fintech sandboxes where created in Australia, Canada, Hong Kong, Malaysia and Singapore. In the energy sector, the British Office of Gas and Energy Markets created their Innovation Link service, a "one stop shop" offering rapid advice on energy regulation to businesses looking to launch new products or business models. When regulatory barriers prevent launching a product or service that would benefit consumers, a regulatory sandbox can be granted to enable a trial (Ofgem, 2018). The Energy Market Authority in Singapore also launched a regulatory sandbox to foster innovation in the energy sector (EMA, 2018).

\section{(2) Grants and other financial incentives}

Many countries have established direct financial support (e.g. business R\&D and innovation grants, institutional funding for public research) to promote research and innovation in key areas for the digital transformation of industry. For instance, the ICT of the Future Programme in Austria provides funding for technology development and innovation projects in the fields of information and communication technologies (Austrian Research Promotion Agency, 2017b). Also in Austria, the Smart and Digital Services Initiative provides funding to support $\mathrm{R} \& \mathrm{D}$ projects in all industries aimed at developing innovative services. Industry 4.0 technologies and blockchain are currently the two priority areas of the programme (FFG, 2018). In Finland, Tekes' Industrial Internet Growth programme ${ }^{5}$ offers financial support to firms that are developing new products, services or business models using Internet of Things solutions. Tekes is also implementing the $5^{\text {th }}$ Gear programme, which funds projects that aim to solve challenges related to the next generation wireless data communications (Tekes, 2017).

Some countries have also implemented indirect funding support mechanisms to foster private investment in research and innovation that is relevant for the digital transformation of industry. For example, as part of the National Plan Industria 4.0, Italy is implementing measures such as 30\% tax deductions for investors in innovative start-ups (with a cap at EUR 1 million for individuals and EUR 1.8 million for firms); hyper-depreciation on tangible and intangible assets related to the digital transformation of industry; and a business accelerator programme to finance the establishment and growth of new companies focused on industry 4.0 technologies (Ministero dello Sviluppo Economico, 2017).

Regulatory uncertainties or barriers to innovation in some areas can be an important factor hindering investments in certain areas of research and innovation. To identify and address these barriers, the European Commission is implementing the "Innovation deals", a pilot inspired by the "Green Deal" Programme in the Netherlands. The goal of Innovation Deals is to identify those barriers and find agreed clarifications of the legislative frameworks together with stakeholders. ${ }^{6}$ This pilot is currently implemented in the area of the Circular

\footnotetext{
$5 \quad$ Tekes is the Finish Funding Agency for Innovation.
}

6 The programme aims to address regulatory uncertainties or barriers to innovation identified by innovators themselves, which may be due to: (1) lack of clarity of EU laws; (2) EU legislation not appropriately supporting innovation and its market uptake; (3) lack of or conflicting standards or norms; and (4) Member States' interpretation of EU law differ from intended meaning. 
Economy - but the approach could be relevant for innovation more generally in the current context of digital transformation (European Commission, 2017d, 2016b).

\section{(3) Dedicated support to research and innovation in AI and Big Data}

Some countries have developed or are working to develop policies to maximize the economic and societal benefits of Artificial Intelligence (AI). They do so by investing in basic and applied research in AI fields and supporting pilot projects in real-word settings, among others. Evidence gathered from the 2017 EC-OECD STI Policy Survey on 42 policy initiatives targeting AI shows that many countries have adopted or are developing AI strategies or plans (see section 2.1.), and that policy initiatives most often target established researchers, firms and public research institutions (Figure 2). In some cases these initiatives also target other technologies, such as Big Data and (less frequently so) cloud computing.

Some initiatives focus on providing funding for research in AI and related areas to universities and research institutions. Such is the case of the Robust Intelligence (RI) programme of the National Science Foundation (USA), which encourages synergies among different research traditions (incl. artificial intelligence, computer vision, human language research, robotics, machine learning, computational neuroscience, cognitive science) as the way of advancing the frontiers of all those research areas (National Science Foundation, 2017).

In the UK, the Engineering and Physical Sciences Research Council (EPSRC) provides funds for the development of new Robotics and Artificial Intelligence (RAI) technologies in UK universities. The University of Manchester, for example, is leading a project to develop robotics technologies capable of operating autonomously and effectively within hazardous environments such as nuclear facilities, while researchers at Imperial College London focus on the field of surgical micro-robotics. Funds will also be provided to support collaboration within the UK Robotics and Autonomous Systems (UK-RAS) Network, to enable researchers in robotics and AI to accelerate the translation of fundamental research into enabling technologies and promote cross-sector growth.

AI public research centres are also proliferating. In Japan, the Artificial Intelligence Research Centre (AIST) is a public research institute established in 2015 that promotes fundamental research in AI technologies and their application to real-world problems. Research focuses in two fields: computing inspired by brain architecture and neurocomputing, and data-knowledge integration. The centre actively cooperates with industry and other research institutions in Japan and worldwide - an illustration of such efforts is the establishment of the Panasonic-AIST Advanced AI Cooperative Research Laboratory (AIST, 2017). The DATAIA Institute, one of the Convergence Institutes in France financed through the Investments for the Future framework, is an interdisciplinary research centre aimed at addressing challenges related to data science, AI and their applications for society (DataIa, 2019). 
Figure 2. Target groups of innovation policy initiatives supporting AI

Note: Evidence based on 42 policy initiatives from 23 countries and the EU. Any given policy initiative may have more than one target group.

Source: Barreneche and Planes-Satorra (forthcoming)

Public-private partnerships are also becoming more common. The Danish Centre for Big Data Analytics Driven Innovation, launched by the Innovation Fund Denmark, is an example. It involves the departments of computer science of three major universities, several IT companies with big data competences as well as public authorities. It aims to make the country a pioneer in exploiting the full potential of big data. The partnership will develop general techniques and tools for big data analytics to be applied within a broad range of domains. The work in the partnership is organised around practical case projects with a large business and societal potential (DABAI, 2017).

A few countries provide grants for business $R \& D$ and innovation in AI. These include Germany's 2017-25 Machine Learning Funding Initiatives, and China's 2015-25 Internet Plus action plan aiming to integrate artificial intelligence and other digital technologies in manufacturing industries (BMBF, n.d.; EC/OECD, 2018a). 


\subsection{Initiatives to support innovative entrepreneurship in the digital age}

The competitiveness of economies in the new digital context may be supported by having a number of firms that strongly exploit the potential of digital technologies. Some countries have already implemented specific programmes to promote digital entrepreneurship and support digital start-ups (i.e. firms that introduce a new digital product, product add-on or service to the market). These initiatives set the focus on different objectives:

- Supporting early-stage business acceleration: In Ireland, the National Digital Research Centre (NDRC) ${ }^{7}$ provides the people, time, space and investment needed at the earliest stages of company creation. It uses an accelerator model, providing modest amounts of capital combined with substantial business development support. They have targeted initiatives for different types of start-up (NDRC, 2017). The NDRC LaunchPad is a digital accelerator that provides teams with early stage business propositions with investment, business support and mentoring to transform ideas into commercially viable start-ups. The NDRC VentureLab provides science-based start-ups that have a strong IP proposition with investment, training and mentoring programme to be able to attract follow-on investments. The NDRC Catalyser targets start-ups and founder teams with deep research-based expertise and technology that address significant global unmet market needs or problems.

- Providing business development support: Tech City UK helps digital entrepreneurs at different stages of the lifecycle of their digital business through various programmes, including the provision of expert courses, networking opportunities as well as mentoring support for scaling up digital technology companies (Tech City UK, 2017). In Korea, 17 Creative Economy and Innovation Centres have been created across the country to support innovative start-ups and SMEs in the fields Internet of Things (IoT), biotech, 5G, cloud computing, big data and artificial intelligence (AI). These centres provide firms with financial support, opportunities for collaborating with big enterprises, advisory services for implementing managerial and technological innovation, and support for accessing new markets (Ministry of Science, ICT and Future Planning, 2017b).

- Strengthening the reputation of the digital start-up ecosystem: In France, the French Tech Initiative aims to create and popularise a brand (the 'French Tech') for French entrepreneurs world-wide. To have this brand, start-ups (which should have a digital component) need to meet certain requirements. Selected start-ups have access to several services. For instance, the Pass French Tech offers start-ups in an hyper-growth stage a simplified and quick access to services (in the fields of financing, access to new markets, innovation, business development) that will help them with their expansion. The French Tech Hubs, currently in 22 cities around the world, are communities of entrepreneurs and investors that provide specialised support to help French start-ups abroad (La French Tech, 2017).

- Strengthening connections with the wider innovation ecosystem: The programme Start-up Sweden organises week-long boot camps (i.e. a gathering of

The National Digital Research Centre (NDRC) was established in 2007 by University College Dublin, Trinity College Dublin, Dublin City University, Dún Laoghaire Institute of Art, Design and Technology \& National College of Art and Design. It is supported by the Department of Communications, Climate Action and Environment. 
entrepreneurs in a specific site allowing them to be exposed and learn from each other) targeted at Sweden's most promising digital start-ups. Ten companies are selected to participate in each edition of the bootcamp, providing them with the opportunity to expand their networks with other companies, investors, potential customers and partners. During the week, they are encouraged to share experiences, they receive practical advice in business development by other start-ups and experts in various fields, and get to practice their sales pitch with coaches and sales pitch experts. Start-ups also have the chance to meet private and public investors in the Sweden Demo Day, where they present small exhibits and pitch for 1 minute in front of investors (Tillväxtverket, 2017).

- Facilitating access to finance: Access to finance is a traditional challenge for startups, but some countries, such as Luxembourg, have created specific schemes targeted at digital start-ups. The Luxembourg Future Fund is a EUR 150 million fund to stimulate the diversification Luxembourg's economy into strategic sectors, including ICT and cleantech. It will invest and co-invest in early-stage and growing innovative European technology SMEs as well as in Venture Capital funds (EIB, 2017). The ICT Seed Fund was set up in 2016 as a public-private partnership, and primarily focuses on venture capital investments in projects that have reached the proof of concept stage in areas such as cybersecurity, FinTech, Big Data, Digital Health and IoT. In order to facilitate the transfer of new technologies resulting from public research, the Seed Fund also aims to invest in promising spin-offs (Gouvernement.lu, 2015).

A relevant challenge for policy makers in the context of digital transformation, where innovation comes from new and often unexpected mixes of technologies and knowledge, is how to design funding schemes that also support innovation in completely new areas or markets. In view of this challenge, the European Innovation Council pilot launched a new Horizon 2020 SME Instrument offering grants that target SMEs and start-ups that innovate in new markets or at the intersection between digital and physical technologies. While this instrument previously supported incremental innovation by pre-defining the topics of support, the new calls are open to any proposals for breakthrough innovations that have the potential to be disruptive and create new markets or revolutionize existing ones. The best SME applicants will be interviewed by a panel of expert evaluators including entrepreneurs who have started up and scaled up innovative enterprises at European or global level, investors and experts involved in the innovation ecosystem (e.g. universities, business schools, innovation hubs, accelerators). The SME Instrument offers innovation grants for feasibility assessment purposes and for innovation development and demonstration, as well as free-of-charge business coaching, access to a range of business acceleration services, and facilitated access to risk finance (European Commission, 2017c). 


\section{Box 4. EU programmes to support digital SMEs and start-ups}

Several programmes have been implemented at EU level to support high-tech and innovative digital SMEs as well as start-ups and promote the diffusion of digital technologies to the wider group of SMEs. These initiatives are summarised in the table below:

Table 4. EU programmes and objectives

\begin{tabular}{ll}
\hline \multicolumn{1}{c}{ Programme } & \multicolumn{1}{c}{ Objective } \\
\cline { 2 - 3 } ICT for Manufacturing SMEs & $\begin{array}{l}\text { Promote the development and adoption of ICT innovations so as } \\
\text { to modernise Europe's manufacturing capabilities. It targets } \\
\text { SMEs that are either suppliers of high-tech or early adopters of } \\
\text { new technologies. SMEs may benefit from: direct financial } \\
\text { support to improve their products or manufacturing processes; } \\
\text { acquiring new technologies and knowledge; accessing new } \\
\text { markets and partners outside their local ecosystem. }\end{array}$ \\
$\underline{\text { Smart Anything Everywhere }}$ & $\begin{array}{l}\text { Support innovation through digital technologies by fostering } \\
\text { collaboration among researchers, large firms and SMEs } \\
\text { facilitated by Europe's network of competence centers. The }\end{array}$ \\
objective is to transfer knowledge and resources across the \\
economy.
\end{tabular}

Note: * High-performance computing (HPC) is the use of super computers and parallel processing techniques for solving complex computational problems. High-performance computing is typically used for solving advanced problems and performing research activities through computer modeling, simulation and analysis.

Source: European Commission. 


\section{Conclusion}

This paper provides a general picture of the types of innovation policy strategies and initiatives implemented in different countries to facilitate a successful transition towards a digital economy. It does not give an exhaustive account of policy strategies and initiatives, but offers an overview of ongoing policy trends and most innovative approaches.

As the innovation policy landscape is constantly evolving, new policy approaches and experiments to support the digital transformation are likely to emerge in the near future, while some of those that are experimental today become more widely adopted. Policy makers would therefore benefit from future efforts aimed at regularly identifying and analysing new policy approaches adopted in different countries. In particular, initiatives related to AI innovation and data access are starting to be developed and implemented in some countries, and thus exploring their characteristics, as well as common trends and specificities, will be of high interest for policy makers tasked with developing those policies. 


\section{References}

ACRAI (2018), Shaping Austria's future positively with Robotics and Artificial Intelligence: White Paper of the Austrian Council on Robotics and Artificial Intelligence - Executive summary, https://www.acrai.at/images/download/ACRAI_Handout_engl.pdf (Accessed 29 March 2019).

AGID (2018), Artificial Intelligence at the service of the citizen - AI White Paper, Agenzia per l'Italia Digitale, https://ai-white-paper.readthedocs.io/en/latest/ (accessed on 26 February 2019).

AI for Humanity (2018), AI for humanity, Direction interministérielle du numérique et du système d'information et de communication de l'Etat (DINSIC), https://www.aiforhumanity.fr/ (Accessed 14 February 2019).

AI Forum (2018), What is the AI Forum of New Zealand?, Available at: https://aiforum.org.nz/ (Accessed 18 May 2018).

AI Hub Europe (2018), German Parliament sets up commission on Artificial Intelligence, AI Hub Europe, https://ai-europe.eu/german-artificial-intelligence/ (accessed on 26 February 2019).

AIST (2017), The Artificial Intelligence Research Centre: What's New, Available at: http://www.airc.aist.go.jp/en/ (Accessed 29 May 2017).

AMNPO (2017), Highlighting Manufacturing USA: National Network for Manufacturing Innovation, Available at: https://www.manufacturing.gov/ (Accessed 12 May 2017).

Apps.co (2017) https://apps.co/ (Accessed 13 September 2017).

Associazione Fabbrica Intelligente Lombardia (2014), Mission, Available at: http://www.afil.it/en/aboutus/mission/ (Accessed 12 May 2017).

Australian Government (2017) The Digital Economy: Opening up the conversation, Department of Industry, Innovation and Science, https://industry.gov.au/innovation/DigitalEconomy/Pages/default.aspx (Accessed 12 October 2017).

Australian Government (2018), Australia's Tech Future: Delivering a strong, safe and inclusive digital economy, Ministry for Industry, Science and Technology, https://www.industry.gov.au/sites/default/files/2018-12/australias-tech-future.pdf (accessed on 08 February 2019).

Australian Government (2018), Digital Health Test Beds program, https://conversation.digitalhealth.gov.au/digital-health-test-beds-program (accessed on 12 February 2019).

Australian Government (2018), Industry Growth Centres, Available at: https://industry.gov.au/industry/Industry-Growth-Centres/Pages/default.aspx (Accessed on 18 May 2018)

Australian Industry Group (2017), Digital Business Kit Manufacturing, Available at: https://digitalbusinesskits.com.au/ (Accessed on 25 July 2017).

Austrian Research Promotion Agency (2017a), -Production of the Future - The programme, Available at: https://www.ffg.at/en/production-future-programme (Accessed on 12 May 2017). 
Austrian Research Promotion Agency (2017b), ICT of the Future, Available at: https://www.ffg.at/en/ictofthefuture (Accessed on 26 June 2017).

Automotive Council UK (2018), New Automotive Technology Roadmap launched, Available at: https://www.automotivecouncil.co.uk/2018/07/new-automotive-technology-roadmap-launched/ (Accessed 22 February 2019).

Barreneche, A. and Planes-Satorra, S. (forthcoming), Digital innovation: Analysis from the 2017 ECOECD STI Policy Survey, Report for the H2020 REITER Project.

BioInnovation (2018), BioInnovation, https://www.bioinnovation.se/in-english/ (accessed on 15 February 2019).

BMBF (2015), Industrie 4.0 - Innovationen fuer die Produktion von morgen.

BMBF(n.d.), Machine Learning / Data Analytics, https://www.softwaresysteme.ptdlr.de/de/maschinelles-lernen.php (accessed on 15 February 2019).

BMBWF, BMVIT and BMDW (2018), Austrian Research and Technology Report 2018, Report of the Federal Government to the Parliament under section 8(2) of the Research Organisation Act, on federally subsidised research, technology and innovation in Austria.

BMWI (2017) Research and innovation: Exchanging knowledge for the products of tomorrow, Available at: http://www.plattformi40.de/I40/Navigation/EN/Industrie40/AreasOfAction/ResearchAndInnovation/research-andinnovation.html (Accessed 11 September 2017).

BMWI (2018), The Federal Government's Artificial Intelligence Strategy 'AI made in Germany'. Bundesministerium für Wirtschaft und Energie, https://www.de.digital/DIGITAL/Redaktion/EN/Standardartikel/artificial-intelligence-strategy.html (Accessed 14 Feb. 2019).

Boog, R., J. Schnobrich, R. Sommer and P. Trompisch (2019), "Plattform Industrie 4.0 Austria: Country policy case study contribution to the OECD TIP Digital and Open Innovation project".

Cap Digital (2017), The French Cluster for Digital Transformation: Organization, Available at: http://www.capdigital.com/en/capdigital/organization/ (Accessed 12 May 2017).

CAP'TRONIC (2017), Competitivité et innovation des PME par l'électronique, Available at : http://www.captronic.fr/Competitivite-et-innovation-des.html (Accessed 18 May 2018).

Catapult (2017), About Catapult, Available at : https://catapult.org.uk/about-us/about-catapult/ (Accessed 12 May 2017).

Chui, M., M. Harryson, J. Manyika, R. Roberts, R. Chung, A. van Heteren, P. Nel (2018) Notes from the AI frontier: Applying AI for social good, McKinsey Global Institute, Discussion Paper December 2018.

CIFAR (2019), AI \& Society, CIFAR, https://www.cifar.ca/ai/pan-canadian-artificial-intelligencestrategy (accessed 29 March 2019).

CIFAR (2017), Pan-Canadian Artificial Intelligence Strategy, CIFAR, https://www.cifar.ca/ai/pancanadian-artificial-intelligence-strategy (accessed on 26 February 2019).

CitizenScience.gov (2018), Helping Federal Agencies Accelerate Innovation through Public Participation, www.citizenscience.gov/\# (accessed on 27 September 2018).

Cluster Fabbrica Intelligente (2014), Cluster Tecnologico Nazionale Fabbrica Intelligente: About CFI, Available online: http://www.fabbricaintelligente.it/en/ (Accessed 25 April 2017) 
Comité de Transformación Digital (2017), Nosotros, https://www.ctdigital.cl/ (Accessed 9 November 2017).

CORFO (2017) Transforma Industrias Inteligentes, http://www.chiletransforma.cl/programa/programaindustrias-inteligentes/ (Accesssed 11 September 2017)

Council for Science, Technology and Innovation (2015), "Report on the $5^{\text {th }}$ Science and Technology Basic Plan", Cabinet Office, Government of Japan, Available online: http://www8.cao.go.jp/cstp/kihonkeikaku/5basicplan_en.pdf (Accessed 9 November 2017).

Data61 (2019), “CSIRO's Data61: Country case study contribution to the OECD TIP Digital and Open Innovation project".

Data61 (2017) http://www.data61.csiro.au/

DataIa (2019), DataIa, https://dataia.eu/index.php/en (accessed on 15 February 2019).

Davies, R. (2015), Industry 4.0: Digitalisation for productivity and growth, European Parliament Research Service (EPRS), Briefing September 2015

Department for Culture, Media and Sport (2017), UK Digital Strategy, Available at: https://www.gov.uk/government/publications/uk-digital-strategy/uk-digital-strategy (Accessed 12 May 2017).

Department of Communications, Climate Action and Environment (2017), Trading Online Voucher Scheme, Available at: http://www.dccae.gov.ie/en-ie/communications/programmes-andschemes/Pages/Trading-Online-Voucher-Scheme.aspx (Accessed 12 May 2017).

Department of Communications, Energy and Natural Resources (2013), Doing more with Digital National Digital Strategy for Ireland, Phase 1- Engagement, Available at: http://www.dccae.gov.ie/enie/communications/publications/Documents/63/National\%20Digital\%20Strategy\%20July\%202013\% 20compressed.pdf (Accessed 12 May 2017).

Department of Economy, Science and Innovation (2017), Stad Antwerpen, Vlaanderen en imec bouwen samen aan een smart city proeftuin [The City of Antwerp, Flanders and imec are building a smart city testing ground together], www.ewi-vlaanderen.be/nieuws/stad-antwerpen-vlaanderen-en-imecbouwen-samen-aan-een-smart-city-proeftuin (in Dutch, accessed on 25 October 2018).

Diels, L., W. Dhooge and T. Creten (2016) "Roadmap for the use of biomaterials in Flemish industrial sectors", Belgian case study for the OECD TIP System Innovation project.

Digital Belgium (2017), Digital Belgium Portal, Available at: http://www.digitalbelgium.be/en (Accessed 12 May 2017).

Digital Catapult (2019), "Digital Catapult: Country policy case study contribution to the OECD TIP Digital and Open Innovation project".

Digital Hub (2017), The Digital Hub, Available at: https://www.thedigitalhub.com/move-to-the-digitalhub/ (Accessed 12 May 2017).

Digital Wallonia (2017), Digital Wallonia: Stratégie numérique de la Wallonie, Available at: https://www.digitalwallonia.be/wallonienumerique/ (Accessed 12 May 2017).

Dutton, T., B. Barron and G. Boskovic (2018), Building an AI World: Report on National and Regional AI Strategies, CIFAR, https://www.cifar.ca/docs/default-source/aisociety/buildinganaiworld_eng.pdf?sfvrsn=fb18d129_4 (accessed on 11 February 2019). 
EC/OECD (2018a), Internet Plus, STIP Compass - International Database on STI Policies, Available at: https://stip.oecd.org/stip/policy-initiatives/2017\%2Fdata\%2FpolicyInitiatives\%2F16863 (Accessed 23 May 2018).

EC/OECD (2018b), Platform of Digital Transformation in Industry, STIP Compass - International Database on STI Policies, Available at: https://stip.oecd.org/stip/policyinitiatives/2017\%2Fdata\%2FpolicyInitiatives\%2F15561 (Accessed 18 May 2018).

EIB (2017), Luxembourg Future Fund (LFF), Available at: http://www.eif.europa.eu/what_we_do/resources/lff/index.htm (Accessed 25 July 2017).

EMA (2018), Regulatory Sandbox, Energy Market Authority, Singapore Government, www.ema.gov.sg/sandbox.aspx (accessed on 05 November 2018).

ENTER.CO (2017) Feria especializada en la actualización tecnológica de las empresas, Available at: http://www.enter.co/especiales/expo-mipyme/expo-mipyme-digital-la-feria-para-mipymes-masgrande-del-pais/ (Accessed 14 November 2017).

Enterprise Ireland (2017), Technology Centres, https://www.enterprise-ireland.com/en/researchinnovation/companies/collaborate-with-companies-research-institutes/technology-centres.html (Accessed 19 October 2017).

Estonian Clusters (2017a), Cluster partners - Technology competence centres, Available at: http://www.estonianclusters.ee/cluster-partners/tehnoloogia-arenduskeskused/ (Accessed 13 September 2017).

Estonian Clusters (2017b), ICT Cluster, Available at: http://www.estonianclusters.ee/estonian-clusters2/ict-cluster-2/ (Accessed 26 July 2017).

Euromentors (2017), About Euromentors, Available at: http://www.euromentors.eu/ (Accessed 13 November 2017)

European Cluster Collaboration Platform (2016), Nano4Health - Creating New Value Chains in "Nanotechnologies for Health" in Flanders, https://www.clustercollaboration.eu/euinitiatives/emerging-industries/nano4health-creating-new-value-chains (accessed on 15 February 2019).

European Commission (2018a), Coordinated Plan on Artificial Intelligence, https://ec.europa.eu/digitalsingle-market/en/news/coordinated-plan-artificial-intelligence (accessed on 15 February 2019).

European Commission (2018b), Digitising European Industry, Available at: https://ec.europa.eu/digitalsingle-market/en/policies/digitising-european-industry (Accessed 23 May 2018).

European Commission (2017a), About Watify, Available at: https://ec.europa.eu/growth/toolsdatabases/dem/watify/about-watify (Accessed 13 November 2017)

European Commission (2017b), ICT Innovation Vouchers Scheme for Regions, Available at: https://ec.europa.eu/digital-single-market/en/ict-innovation-vouchers-scheme-regions (Accessed 12 May 2017).

European Commission (2017c), SME instrument, Available at: https://ec.europa.eu/programmes/horizon2020/en/h2020-section/sme-instrument (Accessed 14 November 2017).

European Commission (2017d), About Innovation Deals, Available at: https://ec.europa.eu/research/innovation-deals/index.cfm?pg=about (Accessed 15 November 2017). 
European Commission (2016a), Advanced Manufacturing Supply Chain Initiative Fund, Available at: https://ec.europa.eu/growth/tools-databases/regional-innovation-monitor/support-measure/advancedmanufacturing-supply-chain-initiative-fund (Accessed 12 May 2017).

European Commission (2016b), Staff Working Document of the Better Regulations for innovationdriven investment at EU level, https://ec.europa.eu/research/innovationunion/pdf/innovrefit_staff_working document.pdf\#view=fit\&pagemode=none (Accessed 15 November 2017).

Eurostat (2015), "Being young in Europe today - Digital world", Eurostat Statistics Explained, http://ec.europa.eu/eurostat/statistics-explained/index.php/Being_young_in_Europe_today__digital_world (Accessed 10 November 2017).

FCA (2015), Regulatory Sandbox, Financial Conduct Authority, www.fca.org.uk/firms/regulatorysandbox (accessed on 05 November 2018).

FCT (2018) The INCoDe.2030, Available at: http://www.incode2030.gov.pt/en/initiative (Accessed 18 May 2018).

Federal Chancellery and Federal Ministry of Science, Research and Business (2016), Digital Roadmap Austria, https://www.digitalroadmap.gv.at/en/ (Accessed 8 November 2017)

Federal Ministry for Economic Affairs and Energy (2017a), 'The background to Plattform Industrie 4.0', Plattform Industrie 4.0, Available at: http://www.plattformi40.de/I40/Navigation/EN/ThePlatform/PlattformIndustrie40/plattform-industrie-40.html (Accessed 12 May 2017).

Federal Ministry for Economic Affairs and Energy (2017b), About Trusted Cloud, Available at: https://www.trusted-cloud.de/en/about-trusted-cloud (Accessed 13 November 2017)

Federal Ministry for Economic Affairs and Energy (2017c), 'The Digital Hub Initiative in Brief', Available at: https://www.de.digital/DIGITAL/Redaktion/EN/Downloads/digital-hub-initiative-inbrief.pdf? blob=publicationFile\&v=3 (Accessed 14 November 2017).

Federal Ministry for Economic Affairs and Energy (2017d), 'Digital Hub Initiative', Available at: http://www.de.digital/DIGITAL/Redaktion/EN/Dossier/digital-hub-initiative.html (Accessed 24 November 2017).

Federal Ministry of Education and Research (2017), The New High-Tech Strategy, Available at: http://www.hightech-strategie.de/de/The-new-High-Tech-Strategy-390.php (Accessed 12 May 2017).

FFG (2018), Smart and Digital Services-Initiative (SDS-I), Austrian Research Promotion Agency, Available at: https://www.ffg.at/programme/smart-and-digital-services (Accessed 2 October 2018).

Flanders Make (2017), Manufacturing Innovation Network, Available at: http://www.flandersmake.be/en (Accessed 12 May 2017).

Flanders Today (2016), "De Block invests EUR 3.25 million in health apps", 9 June 2016, Available at: http://www.flanderstoday.eu/innovation/de-block-invests-eu325-million-health-apps (Accessed 10 November 2017).

Fraunhoffer (2015), "Analysis of the Impact of Robotic Systems on Employment in the European Union", Available online: http://publica.fraunhofer.de/documents/N-366982.html (Accessed 4 May 2017).

Gongolidis, V. (2019), "Research-Create-Innovate Programme: Country policy case study contribution to the OECD TIP Digital and Open Innovation project", General Secretariat for Research and 
Technology (GSRT); Managing and Implementation Authority for Research, Technological Development and Innovation (MIA-RTDI).

Goodman, J., J. Melkers and A. Pallais (2016), "Can online delivery increase access to education?", National Bureau of Economic Research, Working Paper No. w22754, www.nber.org/papers/w22754 (Accessed 10 November 2017).

Gouvernement.lu (2015), L'État luxembourgeois et sept investisseurs ont signé une lettre d'engagement pour constituer un fonds d'amorçage pour start-up ICT, Available at: http://www.gouvernement.lu/5525676/14-schneider-fonds?context=3422869 (Accessed 25 July 2017).

Government of Canada (2018), Innovation Superclusters Initiative, https://www.ic.gc.ca/eic/site/093.nsf/eng/home (accessed on 13 February 2019).

GOV.UK (2019), AI Sector Deal, Department for Business, Energy \& Industrial Strategy https://www.gov.uk/government/publications/artificial-intelligence-sector-deal/ai-sector-deal (Accessed 14 Feb. 2019).

GOV.UK (2017), Industrial Strategy Challenge Fund: For Research and Innovation, Innovate UK, Department for Business, Energy \& Industrial Strategy, and UK Research and Innovation, www.gov.uk/government/collections/industrial-strategy-challenge-fund-joint-research-and-innovation (accessed on 25 October 2018).

Government Office for Development and European Cohesion Policy (2017), Slovenian Smart Specialisation Strategy $-\mathrm{S} 4$, Available at:

http://www.svrk.gov.si/en/areas of work/slovenian smart specialisation strategy s4/ (Accessed 12 May 2017).

Government Offices of Sweden (2018), National Approach to Artificial Intelligence, Ministry of Enterprise and Innovation, https://www.government.se/491fa7/contentassets/fe2ba005fb49433587574c513a837fac/nationalapproach-to-artificial-intelligence.pdf (accessed on 26 February 2019).

Government Offices of Sweden (2016), Smart industry - a strategy for new industrialisation for Sweden, Available at: http://www.government.se/information-material/2016/04/smart-industry---a-strategyfor-new-industrialisation-for-sweden/ (Accessed 12 May 2017).

Government Offices of Sweden (2011), ICT for Everyone- A Digital Agenda for Sweden, Available at: http://www.government.se/contentassets/8512aaa8012941deaee5cf9594e50ef4/ict-for-everyone---adigital-agenda-for-sweden (Accessed 12 May 2017).

Hall, W. and J. Pesenti (2017), Growing the Artificial Intelligence Industry in the UK, Available at: https://assets.publishing.service.gov.uk/government/uploads/system/uploads/attachment_data/file/652 097/Growing_the_artificial_intelligence_industry_in_the_UK.pdf (Accessed 22 May 2018).

IA2030Mx (2018), IA2030Mx: Construyendo una agenda integral e inclusiva para México de inteligencial artificial, https://www.ia2030.mx/ (accessed on 28 February 2019).

IMDA (2017), SMEs Go Digital, Infocomm Media Development Authority, Singapore Government, Available at: https://www.imda.gov.sg/industry-development/programmes-and-grants/small-andmedium-enterprises/smes-go-digital (Accessed 25 July 2017).

IPP (2017a), "Policy rationales and objectives for innovative entrepreneurship", World Bank and OECD Innovation Policy Platform, Available at: https://www.innovationpolicyplatform.org/content/policyrationales-and-objectives-innovative-entrepreneurship . 
IPP (2017b), "Policy rationales and objectives for technology transfer and commercialisation", World Bank and OECD Innovation Policy Platform, Available at: https://innovationpolicyplatform.org/content/policy-rationales-and-objectives-technology-transferand-commercialisation

It's OWL Clustermanagement (2017), On the road to Industry 4.0: Technology transfer in the SME sector, Available online: http://www.its-owl.de/fileadmin/PDF/Informationsmaterialien/2017Technology_Transfer_web.pdf (Accessed 25 April 2017)

ITF (2015), “Automated and Autonomous Driving: Regulation under Uncertainty", International Transport Forum Policy Papers, No. 7, OECD Publishing, Paris, http://dx.doi.org/10.1787/5jlwvzdfk640-en.

Kes, S. (2016), "Smart Regulation for Digital Platforms", Dutch case study for the OECD TIP System Innovation project.

La French Tech (2017) La French Tech, Available at: http://www.lafrenchtech.com/ (Accessed 13 November 2017)

Lernende Systeme (2018), Germany's Platform for Artificial Intelligence, Available at: https://www.plattform-lernende-systeme.de/home-en.html (Accessed 18 May 2018).

MADE (2018), MADE Digital, Available at: https://en.made.dk/digital/ (Accessed 12 February 2019).

McElwee, S. (2014), Why the Voting Gap Matters, Demos, New York.

Ministère de l'Économie et des Finances (2017), Nouvelle France Industrielle : Construire l'industrie française du futur, Available at: https://www.economie.gouv.fr/nouvelle-france-industrielle/accueil (Accessed 12 May 2017).

Ministère de l'Education nationale, de l'Enseignement supérieur et de la Recherche (2013), France Europe 2020: A Strategic Agenda for Research, Technology Transfer and Innovation, Available at: http://www.enseignementsup-recherche.gouv.fr/cid71873/france-europe-2020-1-agenda-strategiquepour-la-recherche-le-transfert-et-l-innovation.html (Accessed 20 April 2017)

Ministerio de Economía, Fomento y Turismo (2019), "Digital Extension Centre: Country policy case study contribution to the OECD TIP Digital and Open Innovation".

Ministerio de Economía, Industria y Competitividad (2017), Industria Conectada 4.0, Available at: http://www.industriaconectada40.gob.es/Paginas/Index.aspx\#inicio (Accessed 12 May 2017).

Ministero dello Sviluppo Economico (2017), Italy's Plan Industria 4.0 (slides), Available at: http://www.sviluppoeconomico.gov.it/images/stories/documenti/2017_01_16Industria_40_English.pdf (Accessed 12 May 2017).

Ministry of Science, ICT and Future Planning (2017a), Press release [in Korean], Available at: http://msip.go.kr/SYNAP/skin/doc.html?fn=8f2138e0b90e2b97f0b677e0008854e0\&rs=/SYNAP/sn3 hcv/result/201711/ (Accessed 9 november 2017).

Ministry of Economy and Trade (2015), Japan's Robot Strategy was Compiled - Action plan toward a New Industrial Revolution Driven by Robots, Available at: http://www.meti.go.jp/english/press/2015/0123_01.html (Accessed 12 May 2017).

Ministry of Education and Research (2014), Estonian Research and Development and Innovation Strategy 2014-2020: "Knowledge-based Estonia", Available at: https://www.hm.ee/sites/default/files/estonian rdi strategy 2014-2020.pdf (Accessed 12 May 2017).

Ministry of Science, ICT and Future Planning (2017b), Creative Economy, The Promise of Renovating Korea, Available at: http://policy.creativekorea.or.kr/eng/ (Accessed 12 May 2017). 
Mustonen, V. (2016), Smart Kalasatama: Smart Kalasatama Helsinki Smart District Living Lab, presentation, Forum Virium Helsinki, https://mycourses.aalto.fi/pluginfile.php/286899/course/section/68401/Smart_Kalasatama_Aalto_VM .pdf (accessed on 25 October 2018).

National Science and Technology Council (2016), The National Artificial Intelligence Research and Development Strategic Plan, National Science and Technology Council, Networking and information Technology Research and Development Subcommittee, October 2016, Available at: https://obamawhitehouse.archives.gov/sites/default/files/whitehouse files/microsites/ostp/NSTC/natio nal_ai_rd_strategic_plan.pdf (Accessed 29 May 2017).

National Science Foundation (2017), Robust Intelligence (RI), Division of Information \& Intelligent Systems, Available at: https://www.nsf.gov/funding/pgm_summ.jsp?pims_id=503305 (Accessed 29 May 2017).

NEDO (2017), Artificial Intelligence Technology Strategy - Strategic Council of AI Technology, Strategic Council of AI Technology, https://www.nedo.go.jp/content/100865202.pdf (accessed on 26 February 2019).

NHS England (2017), Test Beds, Available at: https://www.england.nhs.uk/ourwork/innovation/testbeds/ (Accessed 10 November 2017).

Nordic Council of Ministers (2018), AI in the Nordic-Baltic region, https://www.regeringen.se/49a602/globalassets/regeringen/dokument/naringsdepartementet/20180514 _nmr_deklaration-slutlig-webb.pdf (accessed on 26 February 2019)

Norsk Katapult (2018), Facts about Norwegian Catapult [in Norwegian], Available at: https://norskkatapult.no/katapult-sentrene/

NoTeB (2019), Nordic Test Beds, https://nordictestbeds.org/about/ (accessed on 6 March 2019).

OECD (2019), Digital Innovation: Seizing Policy Opportunities, OECD Publishing, Paris.

OECD (2018), Financial Markets, Insurance and Private Pensions: Digitalisation and Finance, www.oecd.org/finance/private-pensions/financial-markets-insurance-and-pensions-2018.htm.

OECD (2017a), The Next Production Revolution: Implications for Governments and Business, OECD Publishing, Paris, http://dx.doi.org/10.1787/9789264271036-en.

OECD (2017b), Making Innovation Benefit All: Policies for Inclusive Growth, Available at: https://www.innovationpolicyplatform.org/content/making-innovation-benefit-all-policies-inclusivegrowth .

OECD (2017c), New Health Technologies: Managing Access, Value and Sustainability, OECD Publishing, Paris, http://dx.doi.org/10.1787/9789264266438-en.

OECD (2016a), OECD Science, Technology and Innovation Outlook 2016, OECD Publishing, Paris, http://dx.doi.org/10.1787/sti in outlook-2016-en.

OECD (2016b), Stimulating Digital Innovation for Growth and Inclusiveness: The Role of Policies for the Successful Diffusion of ICT, 2016 Ministerial Meeting on the Digital Economy, Background report, OECD Digital Economy Papers No. 256

OECD (2016c), Enabling the Next Production Revolution: the Future of Manufacturing and Services Interim Report, Meeting of the OECD Council at Ministerial Level, Paris, 1-2 June 2016.

OECD (2016d), Innovating Education and Educating for Innovation: The Power of Digital Technologies and Skills, OECD Publishing, Paris, http://dx.doi.org/10.1787/9789264265097-en . 
OECD (2015a), OECD Digital Economy Outlook 2015, OECD Publishing, Paris, http://dx.doi.org/10.1787/9789264232440-en.

OECD (2015b), OECD Innovation Strategy 2015: An Agenda for Policy Action, Meeting of the OECD Council at Ministerial Level, Paris, 3-4 June 2015, Available online:

https://www.oecd.org/sti/OECD-Innovation-Strategy-2015-CMIN2015-7.pdf.

OECD (2015c), The Innovation Imperative: Contributing to Productivity, Growth and Well-Being, OECD Publishing, Paris, http://dx.doi.org/10.1787/9789264239814-en.

OECD (2015d), Data-Driven Innovation: Big Data for Growth and Well-Being, OECD Publishing, Paris. http://dx.doi.org/10.1787/9789264229358-en.

OECD (2015e), System Innovation: Synthesis Report, Available online: https://www.innovationpolicyplatform.org/sites/default/files/general/SYSTEMINNOVATION_FINA LREPORT.pdf

OECD (2008), The Seoul Declaration for the Future of the Internet Economy, Ministerial session, 18 June 2008, Available at: http://www.oecd.org/internet/consumerpolicy/40839436.pdf(Accessed 11 May 2017)

OECD/IEA (2017), Digitalization and Energy, 2017, IEA Publications, International Energy Agency, https://www.iea.org/publications/freepublications/publication/DigitalizationandEnergy3.pdf.

Planes-Satorra, S. and C. Paunov (2017), "Inclusive innovation policies: Lessons from international case studies", OECD Science, Technology and Industry Working Papers, No. 2017/02, OECD Publishing, Paris, http://dx.doi.org/10.1787/a09a3a5d-en.

Plattform Industrie 4.0 (2016), Association Industry Austria - The Platform for Smart Production, available online: http://plattformindustrie40.at/wp-content/uploads/2016/02/FlyerA4 AssociationIndustry-4.0-Austria.pdf (Accessed 25 April 2017)

Rhomberg, W, A. Berger, C. Hartmann, A. Niederl (2016), Industry 4.0 and Participatory Strategic Planning in Austria, Case study prepared for the Austrian Federal Ministry of Transport, Innovation and Technology in the framework of the OECD -TIP Project on System Innovation.

RVO (2017) Service design vouchers, Available [in Dutch] at: https://www.rvo.nl/subsidiesregelingen/service-design-vouchers (Accessed 13 November 2017)

Schwab, K. (2016), The Fourth Industrial Revolution, Penguin, UK.

Sidley (2017) Fintech and Regulatory Sandboxes in the UK, Hong Kong and Singapore, Available at: https://www.sidley.com/en/insights/newsupdates/2017/09/fintech-and-regulatory-sandboxes (Accessed 13 October 2017).

Smart Industry (2017), What are Fieldlabs?, Available at: https://www.smartindustry.nl/fieldlabs/ (Accessed 12 May 2017).

Stolwijk, C. and M. Punter (2019), "Field labs to accelerate the digitization of the Dutch Industry: Country policy case study contribution to the OECD TIP Digital and Open Innovation project", TNO, The Hague.

Tech City UK (2017), Find Out About Us - Tech City UK, Available at: http://www.techcityuk.com/about-us/ (Accessed 12 May 2017).

Tekes (2017), Team Finland Industrial internet Program, Available at: https://www.tekes.fi/en/programmes-and-services/tekes-programmes/industrial-internet--businessrevolution/ (Accessed 12 May 2017). 
The White House (2019), Executive Order on Maintaining American Leadership in Artificial

Intelligence, The White House, https://www.whitehouse.gov/presidential-actions/executive-ordermaintaining-american-leadership-artificial-intelligence/ (accessed on 15 February 2019).

Tian Wen, T. (2018), South Korea to invest 2.2 trillion won in bid to seize the lead in AI technology by 2022, OpenGov Asia, https://www.opengovasia.com/south-korea-to-invest-2-2-trillion-won-in-bid-toseize-the-lead-in-ai-technology-by-2022/ (Accessed 14 February 2019).

Tillväxtverket (2017), Digilyft, Available online: https://tillvaxtverket.se/aktuellaamnen/digitalisering/digilyft-for-industriforetag.html (Accessed 20 April 2017)

UN (2015) Transforming our world: the 2030 Agenda for Sustainable Development, Resolution adopted by the General Assembly on 25 September 2015,

http://www.un.org/ga/search/view_doc.asp?symbol=A/RES/70/1\&Lang=E (Accessed 1 September 2017).

Villani, C. et al. (2018), For a meaningful artificial intelligence: Towards a French and European strategy, Mission assigned by the Prime Minister Édouard Philippe, https://www.aiforhumanity.fr/pdfs/MissionVillani Report ENG-VF.pdf (accessed on 11 February 2019).

Warwick, K. (2013), "Beyond Industrial Policy: Emerging Issues and New Trends", OECD Science, Technology and Industry Policy Papers, No. 2, OECD Publishing, Paris. 


\section{Annex: Definitions}

Digital transformation refers to the transformation of the economy and society as induced by the use of information and communication technologies (ICTs) (OECD, 2016c). These changes are constant and affect virtually all sectors of the economy. In this context, the digital economy has become a common term used both in policy contexts and academia however there is no universally accepted definition of it.

The Internet economy is often used as a synonym of digital economy, although its scope is narrower. In the OECD Declaration for the Future of the Internet Economy, the Internet economy is defined as covering "the full range of our economic, social and cultural activities supported by the Internet and related information and communications technologies (ICT)" (OECD, 2008). The digital economy goes beyond and permeates and impacts countless sectors across the world's economy (OECD, 2015a).

Digital start-ups bring a new digital product, product add-on or service to the market; or create new opportunities for digital transformation of existing business activities and business models (e.g. adoption of digital technologies to increase the efficiency or convenience of a product or service or to enable new functionalities).

Industry 4.0 stands for the implementation of digital technologies into industrial production systems and the increasing automation and connectivity in manufacturing. The term was first used by the German government in 2012 and refers to a strategy aiming to digitalise the German manufacturing sector (BMBF, 2015). The "four" in Industry 4.0 refers to the "fourth industrial revolution" or the "next production revolution", as defined in OECD (2017a) (see below). The previous three industrial revolutions refer to changes brought about by water and steam power, electric power and automation, respectively (Davies, 2015; Schwab, 2016).

Since its initial use, the term Industry 4.0 has been widely adopted by other governments and industry to refer to the development of "smart factories". Smart factories are factories that allow for increased flexibility, mass customization, speed and autonomy in manufacturing, and for large quantities of data being collected. These factories are expected to significantly reduce costs by increasing efficiency, decrease the duration of innovation cycles and allow companies to follow dynamic market trends (Davies, 2015; Schwab, 2016).

Main technological drivers of Industry 4.0 are digital technologies that enable communication between machines, products and humans in Cyber-Physical-Systems (CPS). CPS embed data streams and computation in physical environments and processes (e.g. manufacturing processes). This is realized via Radio Frequency Identification Devices (RFID), which represent chips that have the average size of a rice corn. RFID are attached to products. They are able to transfer data throughout cloud systems to data processing centres that evaluate information and communicate with machines, other products and humans. This enables a new level of synchronisation of manufacturing processes and allows monitoring of product-data in real-time. Artificial intelligence will allow manufacturing systems to go further by self-optimizing automatically, forecasting machine failure, and simulating new manufacturing and product innovations (Davies, 2015; Schwab, 2016). 
The "fourth industrial revolution" or the "next production revolution" entails a confluence of technologies ranging from a variety of digital technologies (e.g. 3D printing, Internet of Things, advanced robotics) to new materials (e.g. bio or nano-based) to new processes (e.g. data driven production, artificial intelligence, synthetic biology). As these technologies have an impact on the production and the distribution of goods and services in practically all sectors, they are expected to have far-reaching consequences for productivity, skills, income distribution, well-being and the environment (OECD, 2017a).

Key digital technologies enabling the digital transformation of industrial production include Internet of Things, Artificial Intelligence, cloud computing, simulation and big data, among others. Figure A1 depicts the main ones. The technologies at the bottom of the figure enable those at the top, as indicated by the arrows. The technologies at the top (in white), which include additive manufacturing (i.e. 3D printing), autonomous machines and systems, and human-machine integration, are the applications through which the main productivity effects in industry are likely to unfold. In combination, these technologies could one day lead to fully automated production processes, from design to delivery (OECD, 2017a).

Figure A.1. The confuence of key technologies enabling the industrial digital transformation

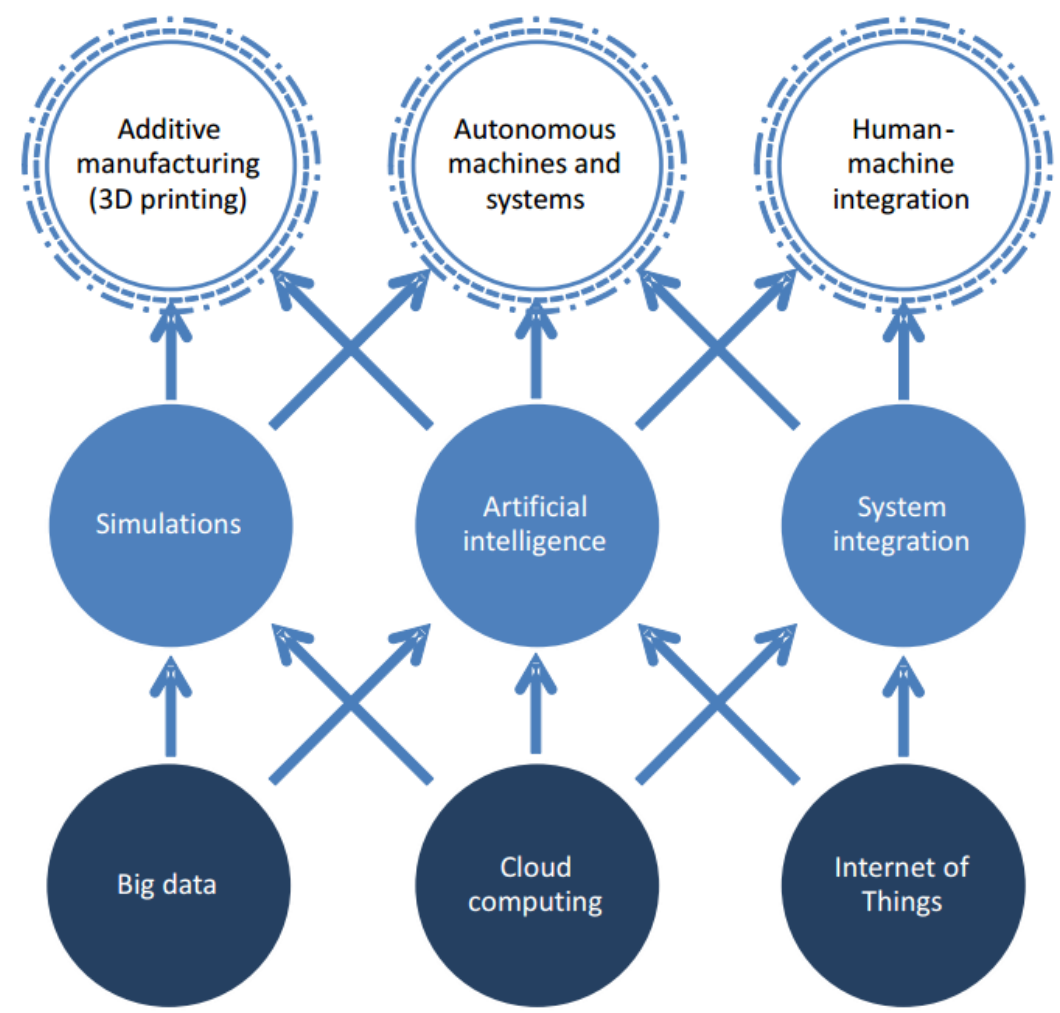

Source: OECD (2017a). 